\title{
Molecular characterization of free tropospheric aerosol collected at the Pico Mountain Observatory: a case study with a long-range transported biomass burning plume
}

\author{
K. Dzepina ${ }^{1,2, *}$, C. Mazzoleni' ${ }^{2,3}$, P. Fialho ${ }^{4}$, S. China ${ }^{2,3}$, B. Zhang ${ }^{2,5}$, R. C. Owen ${ }^{2, * *}$, D. Helmig ${ }^{6}$, J. Hueber ${ }^{6}$, \\ S. $\operatorname{Kumar}^{2,3,{ }^{* * *} \text {, J. A. Perlinger }}{ }^{2,5}$, L. J. Kramer ${ }^{2,7}$, M. P. Dziobak ${ }^{7}$, M. T. Ampadu ${ }^{1}$, S. Olsen ${ }^{8, * * *}$, D. J. Wuebbles ${ }^{8}$, \\ and L. R. Mazzoleni ${ }^{1,2,7}$ \\ ${ }^{1}$ Department of Chemistry, Michigan Technological University, Houghton, MI, USA \\ ${ }^{2}$ Atmospheric Science Program, Michigan Technological University, Houghton, MI, USA \\ ${ }^{3}$ Department of Physics, Michigan Technological University, Houghton, MI, USA \\ ${ }^{4}$ Department of Agricultural Sciences, Azores University, Angra do Heroísmo, Portugal \\ ${ }^{5}$ Department of Civil and Environmental Engineering, Michigan Technological University, Houghton, MI, USA \\ ${ }^{6}$ Institute of Arctic and Alpine Research (INSTAAR), University of Colorado, Boulder, CO, USA \\ ${ }^{7}$ Department of Geological and Mining Engineering and Sciences, Michigan Technological University, Houghton, MI, USA \\ ${ }^{8}$ Department of Atmospheric Science, University of Illinois, Urbana Champaign, IL, USA \\ *now at: Department of Biotechnology, University of Rijeka, Rijeka, Croatia \\ ** now at: US EPA, Research Triangle Park, NC, USA \\ ${ }^{* * *}$ now at: National Center for Medium Range Weather Forecasting, Noida, India \\ **** now at: Xyratex International Ltd, Sacramento, CA, USA
}

Correspondence to: K. Dzepina (kdzepina@mtu.edu) and L. R. Mazzoleni (lrmazzol@mtu.edu)

Received: 15 August 2014 - Published in Atmos. Chem. Phys. Discuss.: 25 September 2014

Revised: 2 April 2015 - Accepted: 7 April 2015 - Published: 5 May 2015

\begin{abstract}
Free tropospheric aerosol was sampled at the Pico Mountain Observatory located at $2225 \mathrm{~m}$ above mean sea level on Pico Island of the Azores archipelago in the North Atlantic. The observatory is located $\sim 3900 \mathrm{~km}$ east and downwind of North America, which enables studies of free tropospheric air transported over long distances. Aerosol samples collected on filters from June to October 2012 were analyzed to characterize organic carbon, elemental carbon, and inorganic ions. The average ambient concentration of aerosol was $0.9 \pm 0.7 \mu \mathrm{g} \mathrm{m}^{-3}$. On average, organic aerosol components represent the largest mass fraction of the total measured aerosol $(60 \pm 51 \%)$, followed by sulfate $(23 \pm 28 \%)$, nitrate $(13 \pm 10 \%)$, chloride $(2 \pm 3 \%)$, and elemental carbon $(2 \pm 2 \%)$. Water-soluble organic matter (WSOM) extracted from two aerosol samples $(9 / 24$ and $9 / 25$ ) collected consecutively during a pollution event were analyzed using ultrahigh-resolution electrospray ionization Fourier transform ion cyclotron resonance mass spectrom-
\end{abstract}

etry. Approximately 4000 molecular formulas were assigned to each of the mass spectra in the range of $m / z 100-1000$. The majority of the assigned molecular formulas had unsaturated structures with $\mathrm{CHO}$ and $\mathrm{CHNO}$ elemental compositions. FLEXPART retroplume analyses showed the sampled air masses were very aged (average plume age $>12$ days). These aged aerosol WSOM compounds had an average $\mathrm{O} / \mathrm{C}$ ratio of $\sim 0.45$, which is relatively low compared to $\mathrm{O} / \mathrm{C}$ ratios of other aged aerosol. The increase in aerosol loading during the measurement period of $9 / 24$ was linked to biomass burning emissions from North America by FLEXPART retroplume analysis and Moderate Resolution Imaging Spectroradiometer (MODIS) fire counts. This was confirmed with biomass burning markers detected in the WSOM and with the morphology and mixing state of particles as determined by scanning electron microscopy. The presence of markers characteristic of aqueous-phase reactions of phenolic species suggests that the aerosol collected at the Pico 
Mountain Observatory had undergone cloud processing before reaching the site. Finally, the air masses of 9/25 were more aged and influenced by marine emissions, as indicated by the presence of organosulfates and other species characteristic of marine aerosol. The change in the air masses for the two samples was corroborated by the changes in ethane, propane, and ozone, morphology of particles, as well as by the FLEXPART retroplume simulations. This paper presents the first detailed molecular characterization of free tropospheric aged aerosol intercepted at a lower free troposphere remote location and provides evidence of low oxygenation after long-range transport. We hypothesize this is a result of the selective removal of highly aged and polar species during long-range transport, because the aerosol underwent a combination of atmospheric processes during transport facilitating aqueous-phase removal (e.g., clouds processing) and fragmentation (e.g., photolysis) of components.

\section{Introduction}

The low scientific understanding of the properties and transformations of atmospheric aerosol is a key source of uncertainty in determining the anthropogenic climate forcing through the aerosol direct, semi-direct, and indirect effects (IPCC, 2013). Organic aerosol (OA) comprises $20-90 \%$ of the atmospheric aerosol mass (Kanakidou et al., 2005; Zhang et al., 2007), and are the least understood component. Atmospheric OA include both primary and secondary OA (POA and SOA, respectively). POA are emitted directly into the atmosphere, while SOA are produced by homogeneous nucleation, oxidative reactions of gaseous organic precursors and condensation of their products onto pre-existing particles, and aqueous phase reactions in cloud, fog, and particulate water (Hallquist et al., 2009). The properties of aerosol in regions downwind of emission sources are impacted by the outflow of pollutants, their chemical transformation, and sinks. In particular, remote locations can be dominated by SOA (Zhang et al., 2007). Highly aged and processed longrange transported ambient aerosol are of particular interest and have chemical composition characteristic of global aerosol (Ramanathan et al., 2001). The long-range transport of aerosol from Asia to North America has received considerable attention (Ramanathan et al., 2001, 2007; Dunlea et al., 2009), but less attention has been placed on aerosol transported from North America to Europe. Ambient watersoluble organic matter (WSOM) is estimated to account for up to $80 \%$ of the OA mass (Saxena and Hildemann, 1996; Sun et al., 2011), but these species are still not well characterized on a molecular level (Reemtsma, 2009). A significant fraction of the WSOM is comprised of higher molecular weight (MW) humic-like substances (HULIS) (Graber and Rudich, 2006) and biogenic SOA (Schmitt-Kopplin et al., 2010; Mazzoleni et al., 2012). Identification of the WSOM composition is challenging. There are thousands of species present with a wide range of elemental compositions and molecular weights containing multiple functional groups such as carboxyl, hydroxyl, carbonyl, nitro, nitrate, and sulfate. Molecular characterization of WSOM is important for understanding its role in fundamental processes such as aerosol light absorption and scattering (Dinar et al., 2006; Shapiro et al., 2009; Nguyen et al., 2013), chemical reduction / oxidation mediation (Kundu et al., 2012), and water uptake and reactivity (Ervens and Volkamer, 2010; Ervens et al., 2011). Furthermore, aqueous SOA formation in clouds might explain the under-predictions of OA concentrations, especially at high altitudes (Carlton et al., 2008). Analytical methods capable of characterizing OA at the molecular level are necessary to tackle these problems.

To date, the Fourier transform ion cyclotron resonance mass spectrometer (FT-ICR MS; Kim et al., 2006) provides the highest mass resolution and accuracy. Typically, the FTICR MS mass resolving power and accuracy used for ambient aerosol analysis are 200 000-400 000 and $<2$ ppm, respectively (Mazzoleni et al., 2010). When combined with an appropriate ionization technique, FT-ICR MS is capable of resolving thousands of chemically different species in a single mass spectrum, and is ideally suited for the analysis of complex mixtures of ambient OA. Electrospray ionization (ESI) is a soft ionization technique that leaves the sample molecules intact and minimizes their fragmentation, and thus is ideal for coupling with FT-ICR MS for detailed molecular level OA characterization (Nizkorodov et al., 2011). Negative mode ESI is especially useful for the ionization of multifunctional oxidized compounds such as carboxyl groups. FT-ICR MS was successfully used for the analysis of ambient OA (Wozniak et al., 2008; Schmitt-Kopplin et al., 2010; Mazzoleni et al., 2012), dissolved organic matter in rain (Altieri et al., 2009a, b, 2012; Mead et al., 2013; Zhao et al., 2013), fog water (Mazzoleni et al., 2010), and sea spray aerosol (Schmitt-Kopplin et al., 2012).

The Pico Mountain Observatory (PMO) is an ideal site for observations of free tropospheric air masses and pollutants from North America after transatlantic transport (Val Martin et al., 2006, 2008a). The observatory is located at $2225 \mathrm{~m}$ above mean sea level (a.m.s.l.) in the summit caldera of a dormant volcano on Pico Island in the Azores archipelago in the North Atlantic $\left(38^{\circ} 28^{\prime} 15^{\prime \prime} \mathrm{N} ; 28^{\circ} 24^{\prime} 14^{\prime \prime} \mathrm{W}\right.$; Fig. S1 in the Supplement). The observatory is typically above the marine boundary layer height of 850-1100 m a.m.s.l. during summer (Kleissl et al., 2007), and is rarely affected by local emissions. Deeper marine boundary conditions with heights up to $1700 \mathrm{~m}$ a.m.s.l. have been reported for colder months (Kleissl et al., 2007) and of about $1500 \mathrm{~m}$ a.m.s.l. for other islands of the Azores archipelago (Remillard et al., 2012), although these are below the altitude of PMO. Measurements at the PMO began in July 2001 with a focus on gaseous species, black carbon, and meteorological parameters. Previous measurements at PMO (e.g., Val Martin et al., 2008a, b) and dispersion model simulations (e.g., Owen et al., 2006) indicated 
that North American outflow of tropospheric ozone and its precursors are frequently encountered at the site. These results were crucial in explaining the evolution of North American gaseous pollution and identified the significant impact of $\mathrm{CO}, \mathrm{O}_{3}, \mathrm{NO}_{x}$, and $\mathrm{NO}_{y}$ from boreal biomass burning pollution on background air composition over the North Atlantic (Honrath et al., 2004; Lapina et al., 2006; Val Martin et al., 2006; Owen et al., 2006; Pfister et al., 2006), and enhanced the understanding of the oxidation of non-methane hydrocarbons (NMHCs) (Helmig et al., 2008; Honrath et al., 2008). Previous research at PMO has shown several-fold increases of NMHCs in anthropogenic and biomass burning plumes. Furthermore, it has been demonstrated that isoprene and ratios of selected NMHC pairs have characteristic signatures that were used for identification of upslope flow conditions (Kleissl et al., 2006) and pollution plume characterization (Helmig et al., 2008). A recent analysis of peroxyacetic nitric anhydride (PAN) showed that higher levels are transported to the PMO during colder, spring months, but not in warmer summer months due to thermal instability (K. Dzepina, J. Roberts, and the Pico Mountain Observatory team, personal communication, 2014; Fischer et al., 2014), consistent with previous estimates (Val Martin et al., 2008b).

Until 2010, the only type of aerosol measured at the PMO was black carbon (BC). Fialho et al. (2005, 2006) developed a method to determine the contribution of $\mathrm{BC}$ and dust from multiwavelength aethalometer measurements. Although typically average free tropospheric aerosol concentrations are low, the long-range transport events bring elevated levels of $\mathrm{BC}$ and dust mass concentrations to PMO. To study these events, new on- and off-line aerosol instrumentation was installed in 2012, as described below.

This paper reports the first detailed chemical characterization of free tropospheric aged aerosol sampled at the PMO during the summer of 2012. Detailed analysis of the WSOM molecular composition using ultrahigh resolution FT-ICR MS was performed for two aerosol samples collected during 24-26 September when a pollution event was observed. Molecular composition of the WSOM, on-line measurements, and laboratory analysis of aerosol are used together with the simulations of a particle dispersion model and satellite data to deduce the emission sources and transformational processes of the fine particles sampled at the PMO.

\section{Measurements and methods}

\subsection{Aerosol measurements at the Pico Mountain Observatory}

New aerosol instrumentation was installed at PMO in 2012, including an optical particle counter (MetOne GT-521, Grants Pass, OR, USA) for sizes in the range between 0.3 and $5 \mu \mathrm{m}$, a nephelometer (EcoTech Aurora 3000, Warren, RI, USA) to measure aerosol light scattering and backscat- tering fraction at three wavelengths (450, 525 and $635 \mathrm{~nm})$, an aerosol sample collector (custom-made at Michigan Tech) for scanning and transmission electron microscopy analysis, and four high-volume air samplers (Hi-Vols; EcoTech HiVol 3000, Warren, RI, USA). The four Hi-Vols were installed at $\sim 50 \mathrm{~m}$ from the PMO, and they collected samples from June through October 2012. They were operated at an average volumetric flow rate of $84 \mathrm{~m}^{3} \mathrm{~h}^{-1}$ for $24 \mathrm{~h}$. Cascade impactors (Tisch Environmental, TE-231 single stage High Volume Cascade Impactor, Cleves, OH, USA) were used for size selection. $\mathrm{PM}_{2.5}$ (particulate matter with aerodynamic diameters $\leq 2.5 \mu \mathrm{m}$ ) was collected on quartz filters (Whatman, $20.3 \times 25.4$ cm Quartz Microfibre Filters, CAT No. 1851-865, Cleves, $\mathrm{OH}$, USA), and particles $>\mathrm{PM}_{2.5}$ were captured on a separate filter (Tisch Environmental, $14.3 \times 13.7 \mathrm{~cm}$ Quartz Filters, part no. TE-230 QZ, Cleves, OH, USA); the results reported here refer only to the $\mathrm{PM}_{2.5}$ samples. Quartz filters were wrapped in aluminum foil, baked for $12 \mathrm{~h}$ at $550^{\circ} \mathrm{C}$, then inserted into antistatic bags (Uline $22.9 \times 30.5 \mathrm{~cm} \mathrm{Re}-$ closable Static Shielding Bags, Pleasant Prairie, WI, USA), and stored at room temperature until use. Typically, filters were inserted in all four Hi-Vols during one visit to the site, and the Hi-Vols were programmed to sample consecutively for $24 \mathrm{~h}$ each. This was done because the site is reachable only via a strenuous hike on rugged terrain (Honrath et al., 2004). Sampled filters were refrigerated locally, transported cold to the US, and kept in a freezer until analysis. A total of 18 filters collected during the 2012 field campaign were selected for further laboratory analysis (Table 1). In 2012, we were unable to collect suitable field blanks due to seasonally above average wet conditions. Thus, a laboratory blank was used to evaluate artifacts. All measurement times reported in this paper are given in local time, which is the same as UTC.

A seven wavelength aethalometer (Magee Scientific, model AE31, $\lambda=370,470,520,590,660,880$ and $950 \mathrm{~nm}$ ) equipped with a "high sensitivity" circular spot size chamber was used to measure the aerosol attenuation coefficient at a flow rate of $7.7 \mathrm{dm}^{3} \mathrm{~min}^{-1}$ without size cut-off. Particulate matter was accumulated on a quartz fibre filter tape $(\mathrm{Q} 250 \mathrm{~F}$ from Pallflex $\left.{ }^{\odot}\right)$. The instrument was set up to automatically advance the tape every $24 \mathrm{~h}$ with a measurement interval of $5 \mathrm{~min}$.

\subsection{Laboratory aerosol measurements}

\subsubsection{Measurements of OC, EC, and inorganic ions}

Aerosol quartz filter samples were analyzed for organic and elemental carbon (OC and EC) with an OC-EC analyzer (Sunset Laboratory Inc., Model 4, Tigard, OR, USA), which uses the thermo-optical transmittance method (Birch and Cary, 1996). The reported results are an average of at least three measurements. OC and EC measurements were also performed for the blanks and subtracted from the aerosol samples. The blank OC values were $13 \%(\mathrm{SD}=8 \%)$ of the 
Table 1. Filters collected during the 2012 field campaign at the Pico Mountain Observatory. Collection times for all filter samples are $24 \mathrm{~h}$, except 6/29 (142 h) and 7/26 (52 h). Sampling times are given in local time (UTC). Average ambient concentrations of filter-collected PM 2.5 species are given, as well as BC mass concentrations measured with the aethalometer at seven wavelengths averaged to the filters collection periods. All measurements are given with their respective standard deviations $(1 \sigma)$. Note BC is not included in the calculated total.

\begin{tabular}{|c|c|c|c|c|c|c|c|c|c|c|c|c|}
\hline \multirow[t]{2}{*}{$\begin{array}{l}\text { Filter } \\
\text { name }\end{array}$} & \multicolumn{2}{|c|}{$\begin{array}{l}\text { Sampling } \\
\text { start }\end{array}$} & \multicolumn{2}{|c|}{$\begin{array}{c}\text { Sampling } \\
\text { end }\end{array}$} & \multirow[t]{2}{*}{$\begin{array}{l}\text { Avg flow } \\
\left(\mathrm{m}^{3} \mathrm{~h}^{-1}\right)\end{array}$} & \multicolumn{6}{|c|}{$\begin{array}{l}\text { Measured ambient mass } \\
\text { concentration }\left(\mathrm{ng} \mathrm{m}^{-3}\right)\end{array}$} & \multirow[t]{2}{*}{$\begin{array}{c}\text { Total } \\
\left(\mu \mathrm{g} \mathrm{m}^{-3}\right)\end{array}$} \\
\hline & $\begin{array}{l}\text { Date } \\
(\mathrm{mm} / \mathrm{dd} / \mathrm{yy})\end{array}$ & Time & $\begin{array}{l}\text { Date } \\
(\mathrm{mm} / \mathrm{dd} / \mathrm{yy})\end{array}$ & Time & & $\operatorname{Org} \pm \mathrm{SD}$ & $\mathrm{EC} \pm \mathrm{SD}$ & $\mathrm{BC} \pm \mathrm{SD}$ & $\mathrm{SO}_{4}^{2-} \pm \mathrm{SD}$ & $\mathrm{NO}_{3}^{-} \pm \mathrm{SD}$ & $\mathrm{Cl}^{-} \pm \mathrm{SD}$ & \\
\hline $6 / 29$ & $06 / 29 / 12$ & $18: 50$ & $07 / 05 / 12$ & $16: 00$ & 50 & $996 \pm 5$ & $58 \pm 1$ & $74 \pm 8$ & $1130 \pm 8$ & $24 \pm 1$ & $<\mathrm{DL}$ & $2.2 \pm 0.6$ \\
\hline $7 / 26$ & $07 / 26 / 12$ & $14: 00$ & $07 / 28 / 12$ & $18: 00$ & 67 & $1038 \pm 16$ & $24 \pm 5$ & $33 \pm 2$ & $184 \pm 30$ & $50 \pm 1$ & $2 \pm 9$ & $1.3 \pm 0.4$ \\
\hline $9 / 1$ & 09/01/12 & 18:00 & $09 / 02 / 12$ & $17: 55$ & 84 & $195 \pm 24$ & $32 \pm 13$ & $32 \pm 9$ & $225 \pm 16$ & $270 \pm 14$ & $<\mathrm{DL}$ & $0.7 \pm 0.1$ \\
\hline $9 / 2$ & $09 / 02 / 12$ & 18:00 & 09/03/12 & $17: 55$ & 84 & $258 \pm 10$ & $34 \pm 7$ & $14 \pm 1$ & $134 \pm 50$ & $209 \pm 15$ & $<\mathrm{DL}$ & $0.6 \pm 0.1$ \\
\hline 9/3 & 09/03/12 & 18:00 & $09 / 04 / 12$ & $17: 55$ & 81 & $124 \pm 7$ & $30 \pm 4$ & $8 \pm 1$ & $99 \pm 39$ & $210 \pm 9$ & $<\mathrm{DL}$ & $0.5 \pm 0.1$ \\
\hline $9 / 14$ & $09 / 14 / 12$ & $15: 00$ & $09 / 15 / 12$ & $15: 00$ & 83 & $390 \pm 29$ & $0.7 \pm 0.1$ & $6 \pm 1$ & $29 \pm 0$ & $20 \pm 0$ & $18 \pm 0$ & $0.5 \pm 0.2$ \\
\hline $9 / 15$ & $09 / 15 / 12$ & $15: 00$ & $09 / 16 / 12$ & $15: 00$ & 83 & $322 \pm 29$ & $1 \pm 1$ & $4 \pm 1$ & $40 \pm 10$ & $24 \pm 12$ & $30 \pm 8$ & $0.4 \pm 0.1$ \\
\hline $9 / 16$ & 09/16/12 & $15: 00$ & 09/17/12 & $15: 00$ & 83 & $365 \pm 17$ & $1 \pm 1$ & $4 \pm 1$ & $47 \pm 20$ & $21 \pm 1$ & $18 \pm 5$ & $0.5 \pm 0.2$ \\
\hline 9/17 & 09/17/12 & $15: 00$ & 09/18/12 & $15: 00$ & 83 & $547 \pm 15$ & $1 \pm 1$ & $4 \pm 1$ & $42 \pm 14$ & $42 \pm 34$ & $8 \pm 4$ & $0.6 \pm 0.2$ \\
\hline $9 / 24$ & $09 / 24 / 12$ & $15: 00$ & $09 / 25 / 12$ & $15: 00$ & 84 & $2049 \pm 16$ & $52 \pm 1$ & $62 \pm 2$ & $470 \pm 14$ & $248 \pm 26$ & $<\mathrm{DL}$ & $2.8 \pm 0.9$ \\
\hline $9 / 25$ & $09 / 25 / 12$ & $15: 00$ & $09 / 26 / 12$ & $15: 00$ & 81 & $735 \pm 46$ & $20 \pm 1$ & $31 \pm 5$ & $75 \pm 8$ & $207 \pm 11$ & $17 \pm 5$ & $1.1 \pm 0.3$ \\
\hline $9 / 26$ & $09 / 26 / 12$ & $15: 00$ & $09 / 27 / 12$ & $14: 55$ & 83 & $707 \pm 86$ & $18 \pm 1$ & $25 \pm 2$ & $289 \pm 41$ & $111 \pm 13$ & $105 \pm 7$ & $1.2 \pm 0.3$ \\
\hline $9 / 27$ & $09 / 27 / 12$ & $15: 00$ & $09 / 28 / 12$ & $14: 55$ & 84 & $778 \pm 1$ & $18 \pm 1$ & $24 \pm 1$ & $266 \pm 23$ & $141 \pm 2$ & $<\mathrm{DL}$ & $1.2 \pm 0.3$ \\
\hline $9 / 28$ & $09 / 28 / 12$ & $15: 00$ & 09/29/12 & $14: 55$ & 81 & $293 \pm 3$ & $21 \pm 2$ & $13 \pm 2$ & $283 \pm 5$ & $192 \pm 13$ & $<\mathrm{DL}$ & $0.8 \pm 0.1$ \\
\hline $9 / 29$ & 09/29/12 & $15: 00$ & 09/30/12 & $14: 55$ & 83 & $444 \pm 1$ & $16 \pm 1$ & $14 \pm 1$ & $208 \pm 25$ & $204 \pm 19$ & $<\mathrm{DL}$ & $0.9 \pm 0.2$ \\
\hline 9/30 & 09/30/12 & $15: 00$ & $10 / 01 / 12$ & $14: 55$ & 83 & $160 \pm 9$ & $14 \pm 1$ & $5.0 \pm 0.4$ & $145 \pm 15$ & $167 \pm 9$ & $<\mathrm{DL}$ & $0.5 \pm 0.1$ \\
\hline $10 / 1$ & $10 / 01 / 12$ & $15: 00$ & $10 / 02 / 12$ & $14: 55$ & 83 & $366 \pm 6$ & $0.3 \pm 0.1$ & $0.8 \pm 0.1$ & $36 \pm 2$ & $29 \pm 18$ & $39 \pm 1$ & $0.5 \pm 0.2$ \\
\hline $10 / 2$ & $10 / 02 / 12$ & $15: 00$ & $10 / 03 / 12$ & $14: 55$ & 83 & $192 \pm 1$ & $1 \pm 1$ & $5 \pm 1$ & $46 \pm 9$ & $52 \pm 2$ & $42 \pm 7$ & $0.3 \pm 0.1$ \\
\hline
\end{tabular}

average ambient OC mass. The blank EC values were below the detection limit and thus no EC blank subtraction was done.

Samples were analyzed for $\mathrm{NO}_{3}^{-}, \mathrm{SO}_{4}^{2-}$, and $\mathrm{Cl}^{-}$with ion chromatography (ICS-2000 ion chromatograph with an IonPac AS11 separator column (Dionex Corporation, Bannockburn, IL, USA)). Samples were prepared for anion analysis by placing seven punches of $1.7 \mathrm{~cm}$ diameter into $12 \mathrm{~mL}$ of nanopure water and sonicating them twice for $30 \mathrm{~min}$ at room temperature. We report averages of the two measurements, blank subtracted for $\mathrm{Cl}^{-}$only; the $\mathrm{Cl}^{-}$in the blank was $48 \%$ $(\mathrm{SD}=21 \%)$ of the $\mathrm{Cl}^{-}$in aerosol samples. The blank $\mathrm{NO}_{3}^{-}$ and $\mathrm{SO}_{4}^{2-}$ values were below the detection limit.

\subsubsection{Ultrahigh resolution ESI FT-ICR MS analysis of WSOM}

We selected two samples named $9 / 24$ and 9/25 (filtercollection periods were 24 September at 15:00 to 25 September at 15:00 and 25 September at 15:00 to 26 September at 15:00) for detailed chemical characterization by ultrahigh resolution mass spectrometry (Table 2). In this paper, unless noted otherwise, " $9 / 24$ " and " $9 / 25$ " always refer to the filter samples collected during these time periods.

A detailed description of the sample preparation, ESI FTICR MS measurements, and data processing is given in the Supplement. Briefly, WSOM samples for FT-ICR MS analysis were prepared using reversed-phase solid-phase extraction (Mazzoleni et al., 2010, 2012; Zhao et al., 2013). The analysis was performed at the Woods Hole Oceanographic Institution (Woods Hole, MA) Fourier Transform Mass Spec- trometry facility with the ultrahigh-resolution hybrid linear ion trap and FT-ICR (7 tesla) mass spectrometer (LTQ FT Ultra, Thermo Scientific, San Jose, CA) with an ESI source. Three replicate measurements were done for each sample in the negative ion mode. The mass resolving power was set at 400000 and the mass accuracy was $<2 \mathrm{ppm}$. Transient coaddition and molecular formula assignment were performed with Composer software (Sierra Analytics, Modesto, CA version 1.0.5) (Mazzoleni et al., 2012). The molecular formula calculator, which uses a Kendrick mass defect (KMD) analysis (Hughey et al., 2001) to sort ions into user-defined homologous series, was set to allow up to 100 carbon, 400 hydrogen, 100 oxygen, 3 nitrogen, and 1 sulfur atom per molecular formula. All molecular formula assignments presented in this paper were assigned using $\mathrm{CH}_{2}$ homologous series consistent with the PREDATOR algorithm (Blakney et al., 2011). The final data set for all samples is composed of the results of two methods for formula assignments: method A, with a de novo cutoff of $m / z 500$ and $\mathrm{C}, \mathrm{H}, \mathrm{N}, \mathrm{O}, \mathrm{S}$ elemental composition; and method B, with a de novo cutoff of $m / z, 1000$ and C, H, O elemental composition (details are given in the Supplement).

\subsubsection{Single particle morphology using scanning electron microscopy}

Quartz filter samples from 9/24 and 9/25 were further analyzed with scanning electron microscopy (SEM) to investigate the morphology of particles and their possible sources. Four portions $(5 \mathrm{~mm} \times 5 \mathrm{~mm})$ were used from different areas of each quartz filter, to obtain representative sample statistics. The samples were coated with a $1.8 \mathrm{~nm}$ thick platinum layer 
Table 2. Chemical characterization of the molecular assignments detected in WSOM for 9/24 and 9/25. Averages of three replicate analyses $(\mathrm{O} / \mathrm{C}, \mathrm{H} / \mathrm{C}, \mathrm{OM} / \mathrm{OC}, \mathrm{DBE}$ and DBE / C) with calculated standard deviation $(1 \sigma)$ of each data subset are given. Subscript "w" denotes values weighted by relative abundance, which have propagated standard error computed using the standard deviations for each subset (as described in Mazzoleni et al., 2012; Zhao et al., 2013).

\begin{tabular}{|c|c|c|c|c|c|}
\hline & & All & $\mathrm{CHO}$ & CHNO & CHOS \\
\hline \multirow[t]{14}{*}{$9 / 24$} & Number & 3960 & 2822 & 1124 & 14 \\
\hline & $\mathrm{O} / \mathrm{C}$ & $0.46 \pm 0.13$ & $0.47 \pm 0.14$ & $0.45 \pm 0.10$ & $0.50 \pm 0.11$ \\
\hline & $\mathrm{O} / \mathrm{C}_{\mathrm{w}}$ & $0.47 \pm 0.01$ & $0.47 \pm 0.01$ & $0.46 \pm 0.01$ & $0.43 \pm 0.27$ \\
\hline & $\mathrm{H} / \mathrm{C}$ & $1.17 \pm 0.26$ & $1.19 \pm 0.27$ & $1.14 \pm 0.22$ & $1.75 \pm 0.31$ \\
\hline & $\mathrm{H} / \mathrm{C}_{\mathrm{w}}$ & $1.17 \pm 0.03$ & $1.17 \pm 0.03$ & $1.14 \pm 0.03$ & $1.88 \pm 1.01$ \\
\hline & $\mathrm{OM} / \mathrm{OC}$ & $1.73 \pm 0.18$ & $1.72 \pm 0.18$ & $1.76 \pm 0.15$ & $1.99 \pm 0.15$ \\
\hline & $\mathrm{OM} / \mathrm{OC}_{\mathrm{W}}$ & $1.73 \pm 0.03$ & $1.72 \pm 0.03$ & $1.77 \pm 0.03$ & $1.91 \pm 0.70$ \\
\hline & DBE & $10.7 \pm 4.0$ & $10.8 \pm 4.3$ & $10.3 \pm 2.9$ & $3.5 \pm 2.6$ \\
\hline & $\mathrm{DBE}_{\mathrm{w}}$ & $10.2 \pm 0.2$ & $10.1 \pm 0.2$ & $10.6 \pm 0.2$ & $1.8 \pm 1.5$ \\
\hline & DBE / C & $0.47 \pm 0.14$ & $0.46 \pm 0.14$ & $0.51 \pm 0.12$ & $0.20 \pm 0.14$ \\
\hline & $\mathrm{DBE} / \mathrm{C}_{\mathrm{W}}$ & $0.47 \pm 0.01$ & $0.46 \pm 0.01$ & $0.50 \pm 0.01$ & $0.13 \pm 0.12$ \\
\hline & Number (structure inferred by AI): Aliphatic $(\mathrm{AI}=0)$ & 2194 & 1686 & 494 & 14 \\
\hline & Olefinic $(0.5>\mathrm{AI}>0)$ & 1563 & 1005 & 558 & 0 \\
\hline & Aromatic $(\mathrm{AI}>=0.5)$ & 203 & 131 & 72 & 0 \\
\hline \multirow[t]{14}{*}{$9 / 25$} & Number & 4770 & 3272 & 1209 & 289 \\
\hline & $\mathrm{O} / \mathrm{C}$ & $0.42 \pm 0.14$ & $0.42 \pm 0.15$ & $0.42 \pm 0.11$ & $0.41 \pm 0.15$ \\
\hline & $\mathrm{O} / \mathrm{C}_{\mathrm{w}}$ & $0.43 \pm 0.01$ & $0.43 \pm 0.01$ & $0.43 \pm 0.01$ & $0.35 \pm 0.06$ \\
\hline & $\mathrm{H} / \mathrm{C}$ & $1.28 \pm 0.30$ & $1.28 \pm 0.30$ & $1.18 \pm 0.23$ & $1.70 \pm 0.27$ \\
\hline & $\mathrm{H} / \mathrm{C}_{\mathrm{W}}$ & $1.26 \pm 0.04$ & $1.26 \pm 0.04$ & $1.19 \pm 0.03$ & $1.73 \pm 0.26$ \\
\hline & $\mathrm{OM} / \mathrm{OC}$ & $1.67 \pm 0.20$ & $1.67 \pm 0.20$ & $1.72 \pm 0.15$ & $1.85 \pm 0.21$ \\
\hline & $\mathrm{OM} / \mathrm{OC}_{\mathrm{w}}$ & $1.68 \pm 0.03$ & $1.66 \pm 0.04$ & $1.74 \pm 0.03$ & $1.79 \pm 0.19$ \\
\hline & DBE & $9.4 \pm 4.23$ & $9.8 \pm 4.4$ & $9.8 \pm 2.9$ & $3.6 \pm 2.3$ \\
\hline & $\mathrm{DBE}_{\mathrm{W}}$ & $9.1 \pm 0.2$ & $9.2 \pm 0.2$ & $10.1 \pm 0.2$ & $3.2 \pm 0.4$ \\
\hline & $\mathrm{DBE} / \mathrm{C}$ & $0.42 \pm 0.16$ & $0.41 \pm 0.15$ & $0.49 \pm 0.12$ & $0.21 \pm 0.14$ \\
\hline & $\mathrm{DBE} / \mathrm{C}_{\mathrm{W}}$ & $0.42 \pm 0.01$ & $0.42 \pm 0.01$ & $0.48 \pm 0.01$ & $0.19 \pm 0.03$ \\
\hline & Number (structure inferred by AI): Aliphatic $(\mathrm{AI}=0)$ & 2740 & 1956 & 506 & 278 \\
\hline & Olefinic $(0.5>\mathrm{AI}>0)$ & 1801 & 1169 & 622 & 10 \\
\hline & $\operatorname{Aromatic}(\mathrm{AI}>=0.5)$ & 229 & 147 & 81 & 1 \\
\hline
\end{tabular}

using a sputter coater (Hummer 6.2) and then imaged using a Hitachi S-4700 field emission SEM (FE-SEM). Over 2000 individual particles from each sample were classified to investigate the relative abundance of spherical, near spherical, soot, and other irregularly shaped particles. Furthermore, we visually classified the soot particles $(N=433$ and 550 for $9 / 24$ and $9 / 25$, respectively) into four classes: (1) heavily coated (embedded soot), (2) partly coated, (3) bare or thinly coated, and (4) attached with other material (partially encapsulated) to investigate the degree of internal mixing after long-range transport (China et al., 2013, 2015). Elemental compositions of individual particles were investigated using energy-dispersive X-Ray spectroscopy (EDS).

\subsection{Gas-phase measurements at the Pico Mountain Observatory}

Nonmethane hydrocarbons were measured at PMO with a cryogen-free, custom-built inlet system interfaced to a gas chromatograph with flame ionization detection (Tanner et al., 2006; Helmig et al., 2008, 2015).

Continuous surface ozone measurements were made by a Thermo-Scientific 49I UV absorption ozone analyzer using ultraviolet absorption of ozone at $254 \mathrm{~nm}$ and the BeerLambert Law to relate the attenuation of light in sample cells to ozone concentration; an inlet was located $4 \mathrm{~m}$ above the ground level. This instrument has been calibrated to a US National Institute of Standards and Technology (NIST) traceable standard, maintained at NOAA Global Monitoring Division in Boulder, Colorado (McClure-Begley et al., 2014).

\subsection{FLEXPART particle dispersion model}

Air mass history was determined using the Lagrangian particle dispersion model FLEXPART (version 8.2; Stohl et al., 1998). FLEXPART simulates the release of thousands of passive tracer air parcels at the PMO location, advecting them backwards in time, providing a representation of the spatial distribution of the air mass at an upwind time referred to as 


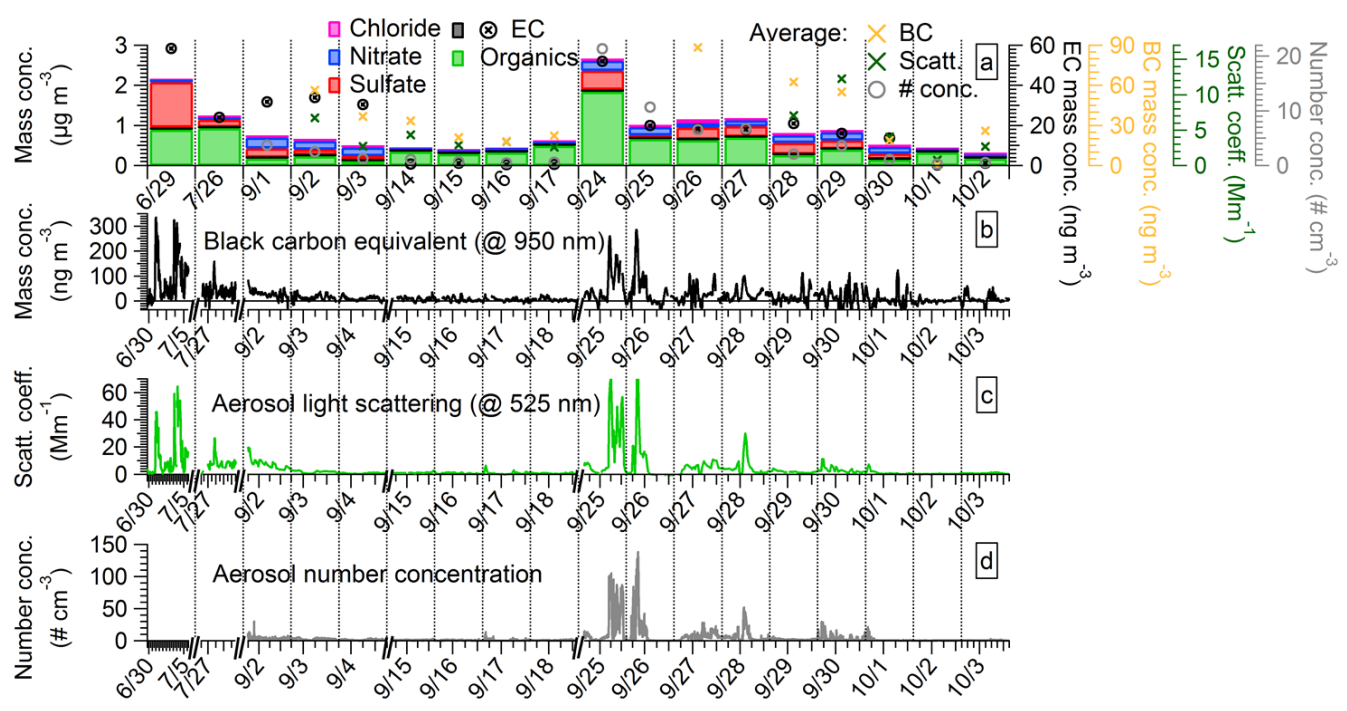

Figure 1. Time series of filter-collected aerosol species during the 2012 field campaign (a). The name of each filter measurement labeled on the $x$ axis is defined as the start date of measurement. Also shown are the time series of the collocated black carbon (b), aerosol light scattering (c), and particle number concentration measurements (d) for the periods overlapping with filter collection. On-line measurements are shown for all overlapping periods and each filter-collection period in (a) matches the continuous measurements in (b-d). Black dashed lines denote the start and end times of filter sampling. The on-line aerosol measurements were averaged for the filter-sampling periods and are represented by symbols in (a); these averages represent a simultaneous comparison with filter-collected species.

a "retroplume". The meteorology data set was a combination of $6 \mathrm{~h}$ meteorological Final Analysis data at 00:00, 06:00, 12:00, and 18:00 UTC, and 6h Global Forecast System data at 03:00, 09:00, 15:00, and 21:00 UTC. All other model settings matched those used in Owen et al. (2006). For each upwind period, the portion of each retroplume in the $0-300 \mathrm{~m}$ layer was multiplied with anthropogenic and fire $\mathrm{CO}$ emission inventories to predict plume sources and ages (Owen and Honrath, 2009).

\section{Results and discussion}

\subsection{Chemical characterization of the Pico Mountain Observatory samples}

The analysis of the bulk chemical composition showed that organic compounds often comprised the largest mass fraction of total aerosol (Table 1). Measured OC was converted to organic matter $(\mathrm{OM})$ using the $\mathrm{OM} / \mathrm{OC}$ ratio of 1.8 adopted from Pitchford et al. (2007), representing the literature consensus for remote areas. The average ambient mass concentration ( \pm standard deviation, $1 \sigma)$ of $\mathrm{OM}+\mathrm{EC}+\mathrm{SO}_{4}^{2-}+$ $\mathrm{NO}_{3}^{-}+\mathrm{Cl}^{-}$at the PMO was $0.9 \pm 0.7 \mu \mathrm{g} \mathrm{m}^{-3}$. On average, OM represents the largest mass fraction $(60 \pm 51 \%)$, followed by sulfate $(23 \pm 28 \%)$, nitrate $(13 \pm 10 \%)$, chloride $(2 \pm 3 \%)$, and EC $(2 \pm 2 \%)$. An overview of the aerosol chemical composition is provided in Fig. 1a. The OM / OC ratio of 1.8 adopted in our analysis is slightly higher than the $\mathrm{OM} / \mathrm{OC}$ ratio of $\sim 1.7$ (Table 2) calculated from FT-ICR
MS analysis of WSOM elemental compositions (Mazzoleni et al., 2010). The measured value of 1.7 is expected to be lower than the total, because of the low sample recovery of highly oxygenated, low molecular weight species (Hallar et al., 2013).

Figure $1 \mathrm{~b}-\mathrm{d}$ show the continuous measurements of BC mass concentration, aerosol light scattering coefficient, and number concentration for time periods overlapping with the filter-collection. The average $\mathrm{BC}$ mass concentration over the filter-collection sampling periods (Fig. 1a) varied between 0.82 and $74 \mathrm{ng} \mathrm{m}^{-3}$ (Table 1), the light scattering coefficient between 0.2 and $16.3 \mathrm{Mm}^{-1}$, and the particle number between 0.3 and 21 particles $\mathrm{m}^{-3}$. Correlations between total filter-collected aerosol mass and on-line aerosol measurements were very good, as shown in Fig. S2 (with an $r^{2}$ of $0.80,0.90$, and 0.93 for BC mass concentration, the scattering coefficient, and the number concentration, respectively). This indicates that the measurements of filtercollected aerosol captured the major trends observed by the continuous aerosol measurements (Fig. 1).

\subsection{Characterization of the air masses during 24-26 September 2012}

This section describes the two sampling periods selected for this case study and provides evidences that the aerosol is representative of the described sources. An increase in the measured aerosol mass concentration and light scattering was observed during September. The highest loading of filter-collected aerosol was observed on $9 / 24$, followed by 

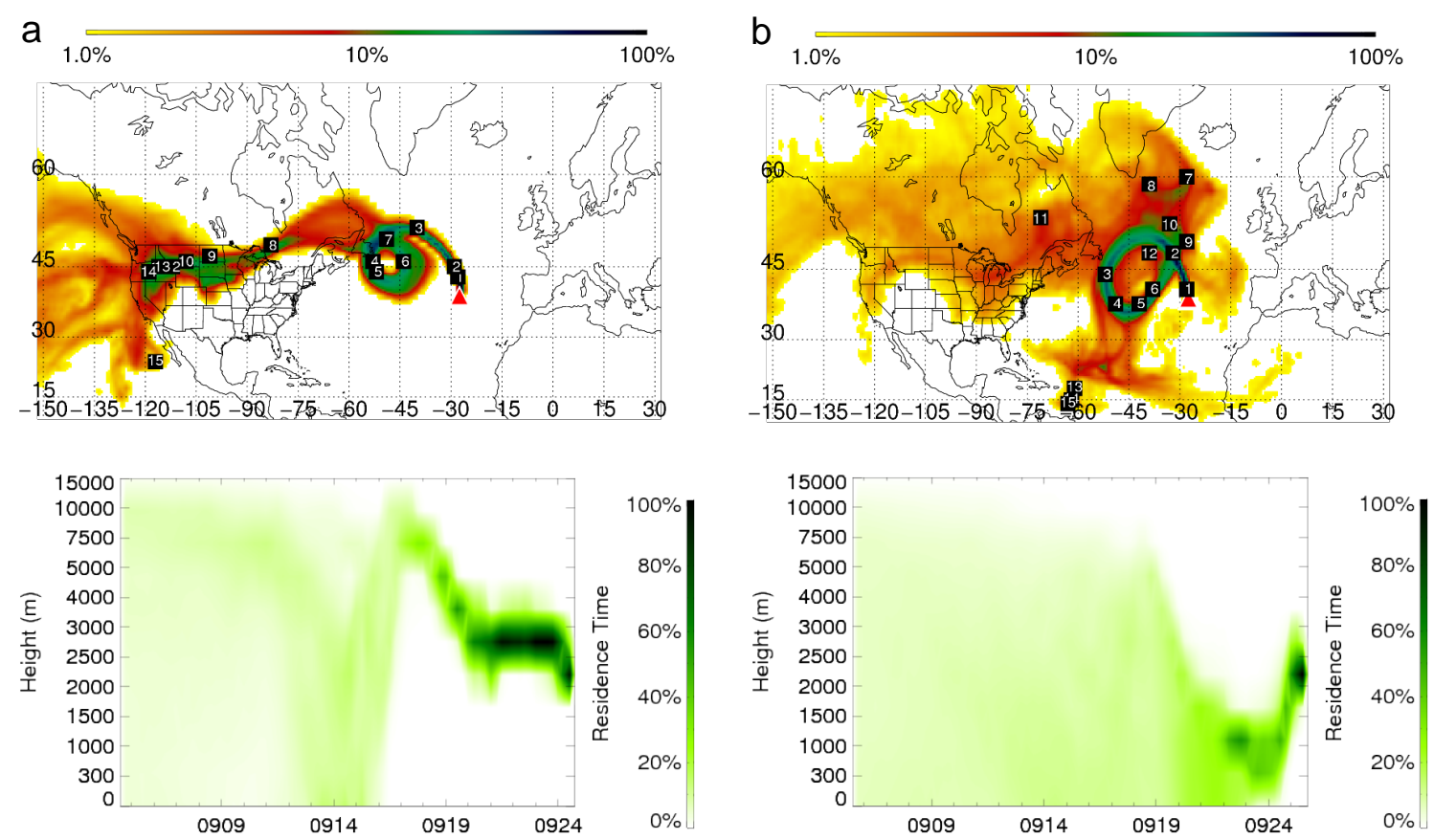

Figure 2. Examples of representative FLEXPART retroplumes for the $9 / 24$ (a) and 9/25 (b) with the upwind time labeled by white numbers in days at each location of the plume. In (a) the retroplume simulation is for 25 September at 06:00 (peak aerosol values (Fig. 1)). In (b) the retroplume simulation is for 26 September at 06:00 (low aerosol values (Fig. 1)). Times are in UTC (local time). FLEXPART retroplumes for the entire periods are given in Figs. S4 and S5. Residence times of retroplumes are normalized by each vertical interval in the lower plots to better visualize the distribution along an irregular height scale.

decreased mass concentrations on 9/25 (Fig. 1a). Similar trends were also observed in the continuous measurements (Fig. 1b-d). The event of interest started on 25 September at approximately 04:00 and lasted until the 26 at approximately 02:00 (Fig. 1b-d). The observed elevated aerosol concentrations are explained by the arrival of biomass burning smoke from North America. September was a dry month and several US states were experiencing an intense drought (NOAA National Climatic Data Center, 2012). Consequently, widespread wildfires were observed in the US northwest and northern Rockies. The wildfire activity is corroborated by the Moderate Resolution Imaging Spectroradiometer (MODIS) satellite daily fire counts (NASA and University of Maryland, 2002), showing the most intense wildfire activity in the northwestern US (Fig. S3 in the Supplement). Additionally, the Level 3 aerosol optical depth (AOD) dark target (Levy et al., 2007) product $\left(1^{\circ} \times 1^{\circ}\right)$ retrieved by MODIS Terra/Aqua at $550 \mathrm{~nm}$ (http://disc.sci.gsfc. nasa.gov/giovanni, accessed on 22 July 2014) indicated a large increase from mid to late September over the northwestern US (data not shown).

The FLEXPART retroplumes show that the transport patterns changed significantly within $48 \mathrm{~h}$, resulting in the arrival of air masses with different chemical signatures to the PMO (retroplumes for 9/24 and 9/25 are given in Figs. 2, S4 and S5). During the $9 / 24$ period, the average modeled
CO age was 12.4 days. A large portion of the retroplumes intersected the northwestern US regions of intense wildfires activity during 13-15 September (Figs. 2 and S3). A few retroplumes (Fig. S4e-g) were lifted to the free troposphere within the next day and encountered a high pressure system before arriving at PMO. Retroplumes during the 9/25 period had a CO tracer age of 14.7 days and were characterized by gradual shift of the transport heights from the middle free troposphere to the marine boundary layer with reduced influence from the US. Retroplumes subsided and entered the marine boundary for 2 days before arriving at PMO (Fig. S5e-h). Therefore, the air masses arriving at PMO during 24-26 September were influenced by the US biomass burning, while those that arrived during $9 / 25$ were also influenced by the marine boundary layer. Simulated contributions of FLEXPART CO from various sources for September are given in Fig. S6.

We also examined the occurrence of upslope flow due to mechanical lifting (Zhang et al., 2014). No occurrence of upslope flow was observed for the period of 24-26 September. This suggests that measurements during those dates were not affected by local emissions.

\subsubsection{Non-methane hydrocarbon measurements}

NMHCs have been widely used as tracers for anthropogenic and biomass burning emissions (Helmig et al., 


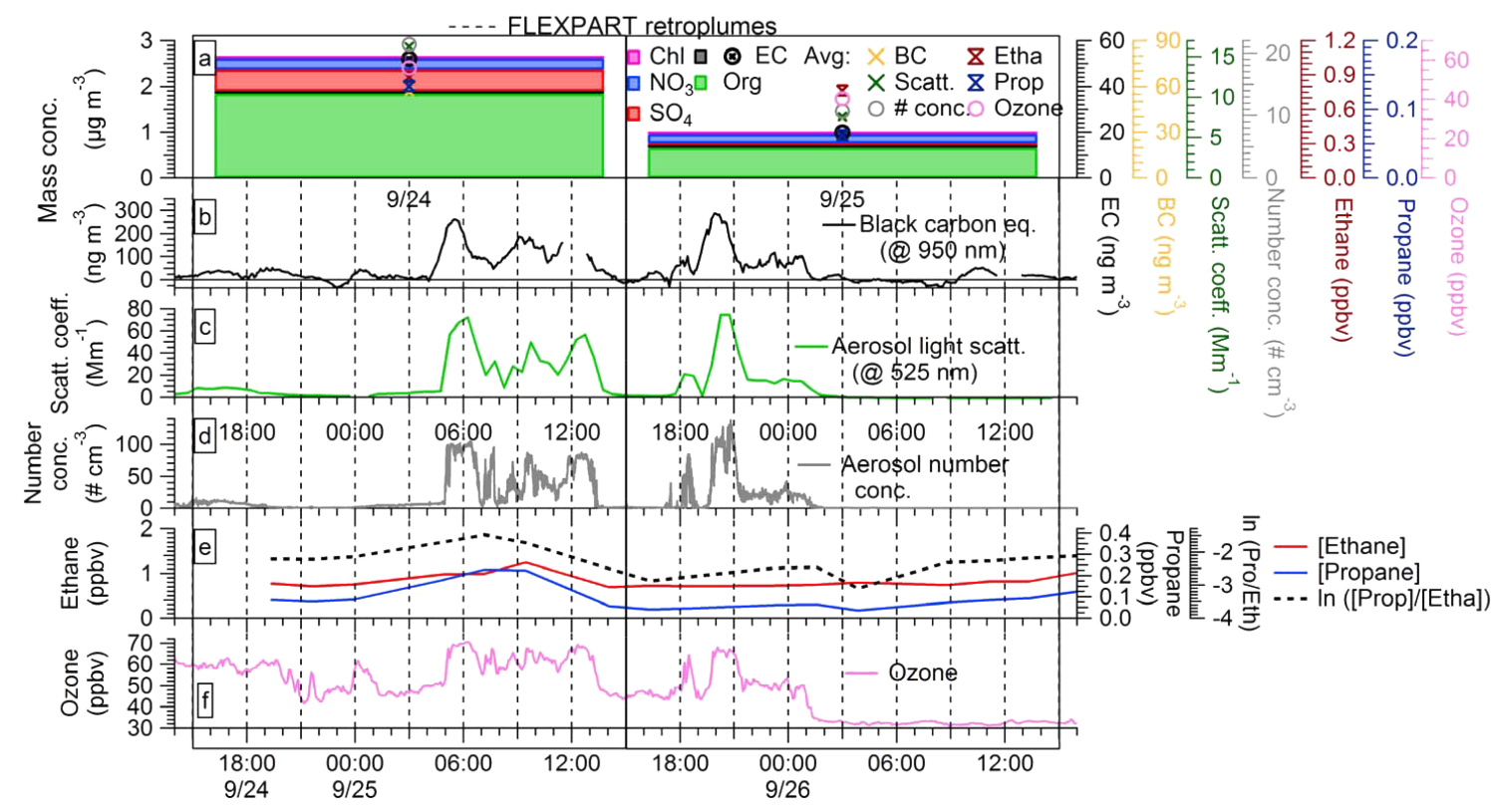

Figure 3. Comparison of aerosol measurements (a-d) during the 24-26 September case study with gas-phase measurements of ethane, propane (e) and ozone (f). On-line measurements are also averaged during the filter-sampling periods (a). Marked within the figure are the times of filter-collection periods (black rectangular shapes, as given in Table 1) and FLEXPART retroplume simulations (dashed lines, as shown in Figs. 2, S4 and S5). Times and dates are shown in the $x$ axis of (d) and (f).

2008). Due to their different oxidation rates, mole fractions of different NMHCs exponentially decline at different rates during atmospheric transport allowing the natural $\log$ of $\mathrm{NMHC}_{1} / \mathrm{NMHC}_{2}$ (e.g., $\ln ([$ propane]/[ethane])) to be used as a linear measure of photooxidation and transport time. $\ln ([$ propane]/[ethane]) has been demonstrated to be a sensitive indicator for identifying pollution signatures and transport time to PMO (Helmig et al., 2008, 2015). Measured ethane and propane are shown together with the filtermeasured species and continuous aerosol measurements for comparison in Fig. 3a-e. The mixing ratios of ethane and propane increased from 0.78 and $0.09 \mathrm{ppbv}$ at $19: 20$ in the evening of 24 September to a maximum of 1.25 and $0.22 \mathrm{ppbv}$ at 09:30 in the morning of 25 September. This was followed by a clear decrease in ethane and propane to average mixing ratios of 0.76 and 0.06 . Decreases in NMHC mixing ratios were also evident from the decrease of $\ln$ ([propane]/[ethane]) (Fig. 3e). The same trend was observed in the ozone mixing ratios during the case study period (Fig. 3f). The decreases in ethane, propane and ozone mixing ratios, as well as in $\ln ([$ propane]/[ethane]), suggest a significant change in the air masses transport and history, from less aged and more polluted air masses during measurement period of $9 / 24$ to more aged and cleaner during measurement period of 9/25, in agreement with the FLEXPART findings. The full record of gas-phase species measured during periods overlapping with Hi-Vols sampling is shown in Fig. S7.

\subsubsection{Scanning electron microscopy single particle analysis}

Representative SEM images for $9 / 24$ and $9 / 25$ are shown in Fig. 4a and b, respectively. A higher fraction of spherical particles was observed on 9/24 (43\%) compared to $9 / 25$ $(18 \%)$. However, the fraction of near spherical particles was lower on 9/24 (23\%) compared to 9/25 (29\%). Spherical particles observed on $9 / 24$ and $9 / 25$ were likely tar balls (TBs) with diameters in the range of 70-1800 nm (Fig. 4cd). TBs are spherical, organic amorphous particles composed of carbon and oxygen abundant in biomass burning aerosol (Adachi and Buseck, 2011; China et al., 2013; Pósfai et al., 2003, 2004; Tivanski et al., 2007). The EDS analysis of spherical and near spherical particles shows that they were mostly composed of $\mathrm{C}$ and $\mathrm{O}$, consistent with the hypothesized identification. As described by China et al. (2013), soot particles emitted from biomass burning are often heavily coated (embedded) with other material. Thus, we visually classified the soot particles and found that for the $9 / 24$ event, $46 \%$ of the soot particles (with respect to the total number of classified soot particles) were heavily coated (Fig. 4eh), compared to only $17 \%$ on $9 / 25$. The higher fraction of heavily coated soot particles observed for $9 / 24$ is consistent with the air mass being most likely influenced by biomass burning. Finally, 34 and $58 \%$ of soot was partly coated, 11 and $17 \%$ thinly coated, and 7 and $8 \%$ partially encapsulated, for $9 / 24$ and $9 / 25$, respectively. Note that tar balls are likely not water-soluble and therefore, the ultrahigh resolution mass 
spectrometry analysis of WSOM presented below probably does not probe them.

\subsection{Molecular characterization of the $9 / 24$ and $9 / 25$ samples}

\subsubsection{Mass spectra and molecular formula assignments}

The exact mass measurements of the ultrahigh resolution FTICR MS allow for unequivocal molecular formula assignments of WSOM in the form of $\mathrm{C}_{c} \mathrm{H}_{h} \mathrm{~N}_{n} \mathrm{O}_{o} \mathrm{~S}_{s}$, where $c, h$, $n, o$, and $s$ are integer numbers of $\mathrm{C}, \mathrm{H}, \mathrm{N}, \mathrm{O}$, and $\mathrm{S}$ atoms. Molecular formulas were assigned to $68-78 \%$ of the total ion current depending on the sample and whether the assignment of molecular formulas was performed by method A or B. The three replicate measurements of $9 / 24$ and $9 / 25$ analyzed by method A with $\mathrm{C}, \mathrm{H}, \mathrm{N}, \mathrm{O}$, and $\mathrm{S}$ resulted in 72 and $78 \%$ assignments of total ion current. Additional molecular formulas at the higher $m / z$ values were assigned with method B for species containing $\mathrm{C}, \mathrm{H}$, and $\mathrm{O}$ only. When methods $\mathrm{A}$ and $\mathrm{B}$ were combined, the assignments yielded a total of 3960 and 4770 monoisotopic molecular formulas for $9 / 24$ and $9 / 25$ (Table 2). Polyisotopic formula assignments containing naturally occurring ${ }^{13} \mathrm{C}$ and ${ }^{34} \mathrm{~S}$ were also detected in aerosol samples. The vast majority of all assigned monoisotopic formulas contained corresponding ${ }^{13} \mathrm{C}$ assignments (91-95\%), while $69-100 \%$ of ${ }^{32} \mathrm{~S}$-containing monoisotopic ions also contained formula assignments with ${ }^{34} \mathrm{~S}$, consistent with previous findings (e.g., Mazzoleni et al., 2012).

The reconstructed mass spectra of molecular formulas assigned to $9 / 24$ and $9 / 25$ (Fig. 5) indicate a high isobaric complexity due to the large number of monoisotopic anions (Table 2). Examples of the isobaric complexity are illustrated for the range of $m / z 409.0-409.3$ (Fig. 5c and g) with 12 and 21 molecular assignments for $9 / 24$ and $9 / 25$. Mass spectra of both samples are characterized by high $m / z$ values with a maximum relative abundance of the detected ions in the range of $m / z 400-500$. Approximately $2 / 3$ of the molecular assignments are for anions with $m / z>400$. This is a unique feature of the WSOM compounds at PMO that has not been observed in other samples analyzed using similar FT-ICR MS methods. Previously, the maximum relative abundance of molecular assignments detected in aerosol (Wozniak et al., 2008; Schmitt-Kopplin et al., 2010; Mazzoleni et al., 2012) and cloud water (Zhao et al., 2013) was observed between $m / z 200$ and 400. Moreover, aerosol collected at various locations typically does not have a significant number of compounds detected $>m / z 400$ (e.g., Wozniak et al., 2008; Mazzoleni et al., 2010). The higher molecular weight ranges observed in the PMO WSOM are likely a consequence of the combined oxidative aging and aqueous-phase oligomers formation during the long-range transport.

The assigned molecular formulas were divided into four groups based on their elemental composition and named after the atoms included: $\mathrm{CHO}, \mathrm{CHNO}, \mathrm{CHOS}$, and CHNOS.
The highest number of molecular assignments were $\mathrm{CHO}$ group species, which account for $\sim 70 \%$ of the total number (Table 2). CHO species had the highest observed relative abundances with a maximum in the range of $m / z 400$ 500 (Fig. 5). The second most abundant group of species was CHNO, representing $\sim 26 \%$ of the molecular assignments (Table 2). The maximum relative abundance of the CHNO group was at slightly higher $m / z$ values compared to the $\mathrm{CHO}$ compounds. We observed a surprisingly small number of S-containing species. There were 14 and 289 CHOS molecular formulas in $9 / 24$ and $9 / 25$, representing 0.4 and $6 \%$ of the assignments. The CHOS species detected in $9 / 24$ had low relative abundances; only two ions had relative abundances $>1.5 \%\left(\mathrm{C}_{12} \mathrm{H}_{26} \mathrm{SO}_{4}\right.$ and $\left.\mathrm{C}_{14} \mathrm{H}_{30} \mathrm{SO}_{4}\right)$. Most of the CHOS assignments in 9/25 also had low relative abundances $(<2 \%)$, but 12 have relative abundances $>5 \%$. Finally, a very small number of low relative abundance CHNOS compounds was detected in $9 / 24$ and $9 / 25(N=7$ and 28$)$. Due to their high water solubility, it is not likely that nitrooxy organosulfates will be observed after long-range transport because they are likely removed by cloud processing. This observation is also consistent with the low number of sulfurcontaining species. Thus, the CHNOS molecular formula assignments are not presented here.

Overall, the Kendrick plots of the molecular assignments for the two samples (Fig. 6a and d) have higher KMD and nominal Kendrick mass (NKM) values with a narrow range and an overall more uniform distribution compared to previous measurements with similar ESI FT-ICR MS measurement parameters. For example, in comparison with the cloud water WSOM reported by Zhao et al. (2013), the free tropospheric aerosol WSOM studied here had a narrower spread in the NKM over the observed mass ranges. This narrow and uniform distribution has not been observed in other Kendrick plots of aerosol WSOM (e.g., Kourtchev et al., 2013) and may indicate highly processed aerosol. Ultrahigh-resolution FT-ICR MS measurements of a Suwannee River Fulvic Acid standard, a model for HULIS, yield very similar distribution in the Kendrick plot (Stenson et al., 2003).

The van Krevelen diagrams for the $9 / 24$ and $9 / 25$ in Fig. $6 \mathrm{~b}$ and e show a narrow and homogeneous distribution with aliphatic and olefinic species (Table 2). For example, the range of values of $\mathrm{O} / \mathrm{C}$ ratio for aerosol WSOM collected at the PMO vs. the Storm Peak Laboratory (Mazzoleni et al., 2012 ) is $0.13-1.48$ vs. $0.07-1.80$ (Table 3 ). Mass resolved $\mathrm{H} / \mathrm{C}$ diagrams are given in Fig. S8 to indicate the quality of the molecular assignments of the ultrahigh-resolution FTICR mass spectra. The similarity in the distribution of species in the mass resolved $\mathrm{H} / \mathrm{C}$ diagram to those reported previously (Schmitt-Kopplin et al., 2010) is further discussed in the sections below.

Structural information for the assigned molecular formulas is inferred from the double bond equivalent (DBE) values; the calculation of DBE is given in the Supplement. A wide range of DBE values were observed for $9 / 24$ and $9 / 25$ 

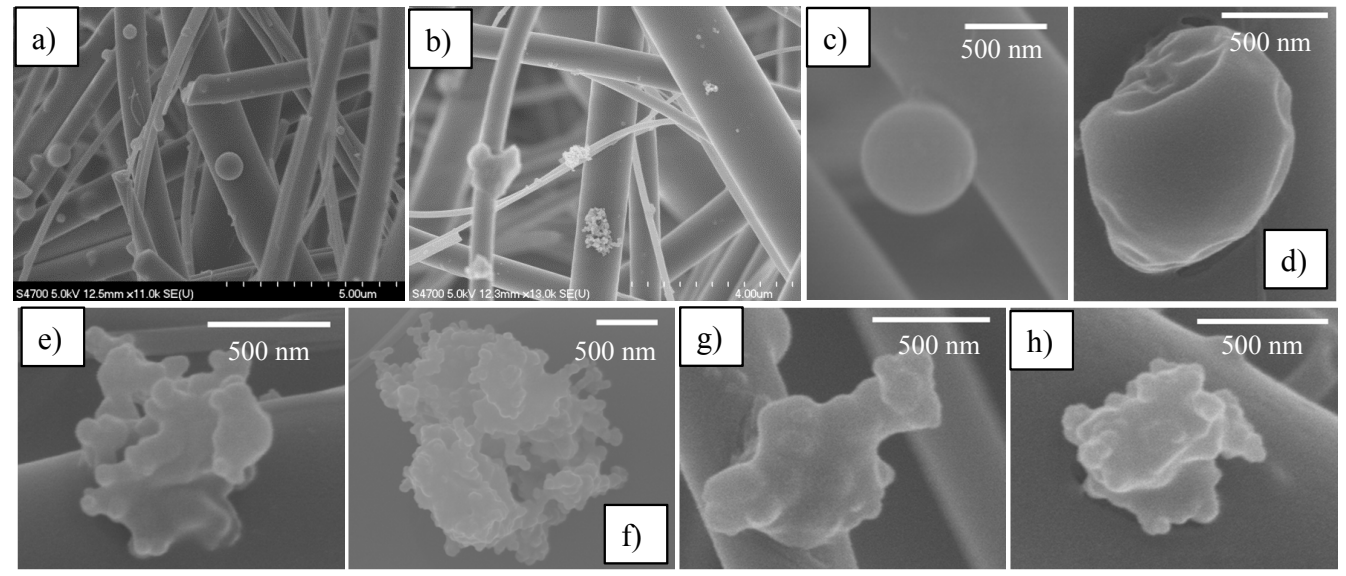

Figure 4. Representative SEM images of particles collected on 9/24 (a) and 9/25 (b). Also shown are examples of spherical (43 and $18 \%$ in $9 / 24$ and $9 / 25$, respectively) (c), near spherical particles (23 and $29 \%$ in $9 / 24$ and 9/25, respectively) (d), and embedded soot particles (46 and $17 \%$ in $9 / 24$ and $9 / 25$, respectively) (e-h).
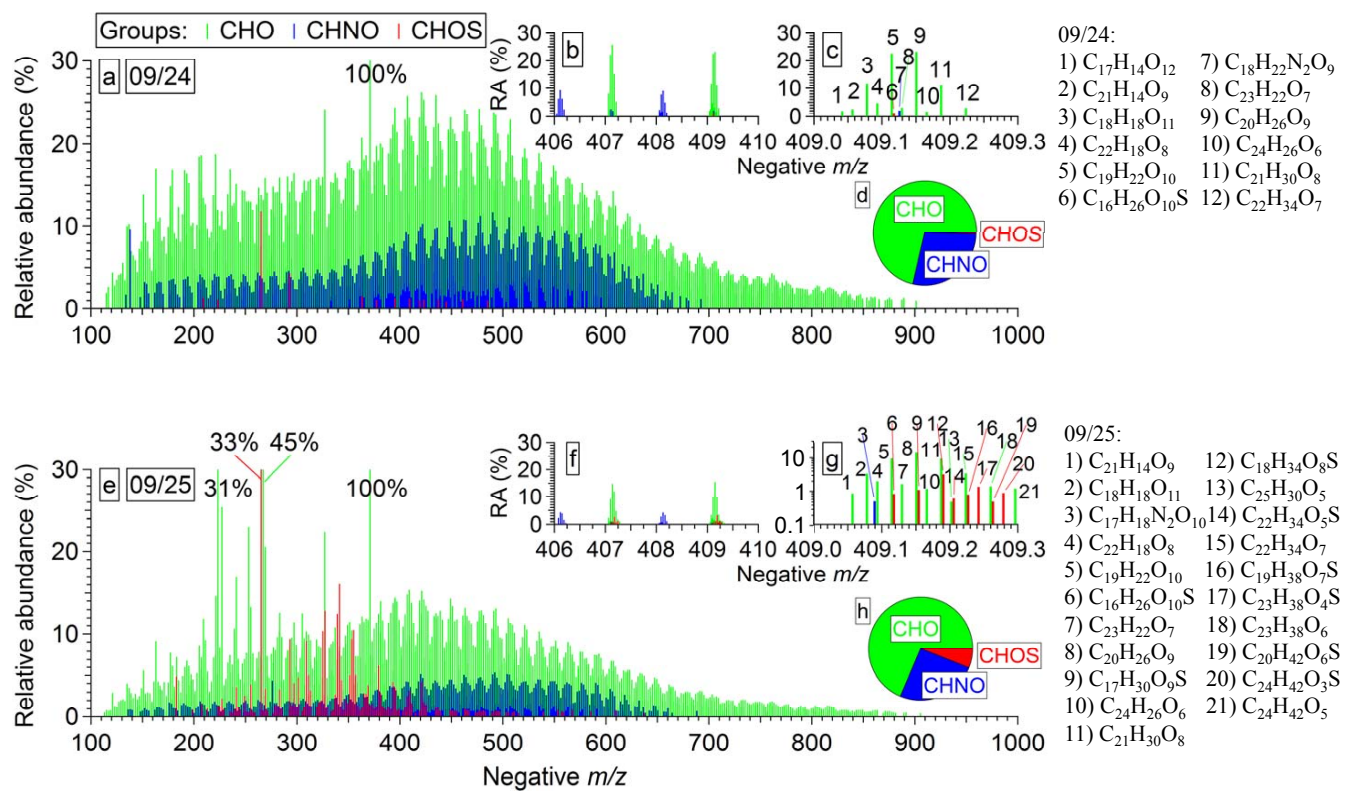

Figure 5. Reconstructed mass spectra of the assigned monoisotopic ions for PMO WSOM on 9/24 (a-d) and 9/25 (e-h) with CHO, CHNO and CHOS groups of compounds. Number fractions of detected monoisotopic formula assignments in all groups are given as the pie charts in (d) and (h). An illustration of the isobaric complexity is shown as an excerpt of mass spectra in the ranges of $m / z 406-410$ (b and f) and $m / z$ 409.0-409.3 (c and g). All identified molecular formulas between $m / z 409.0$ and 409.3 are listed in the order of appearance.

(Fig. 6c and f) consistent with the molecular complexity of the samples described above. Aromaticity index (AI) analysis of PMO WSOM supports the observations from the elemental ratios and DBE values (AI calculation is described in the Supplement). In both samples, most of the species had aliphatic $(\sim 55 \%)$ and olefinic $(\sim 40 \%)$ character with only a small contribution from aromatic species $(\sim 5 \%)$ (Table 2$)$. This finding is in agreement with previous studies of ambient aerosol (Schmitt-Kopplin et al., 2010; Mazzoleni et al., 2010, 2012; LeClair et al., 2012), which also found that the major- ity of species has aliphatic and olefinic character. Examples which illustrate the chemical composition complexity available with FT-ICR MS analysis are given in the Supplement (Fig. S9).

\subsubsection{Characteristics of the CHO molecular formulas}

The CHO species presented in the isoabundance van Krevelen diagram (Fig. 7a-b) for 9/24 and 9/25 had average O / C ratios of 0.47 and 0.42 and average $\mathrm{H} / \mathrm{C}$ ratios of 1.19 and 1.28 (Table 2). Isoabundance is defined as the total relative 
$-\mathrm{CHO} \bullet \mathrm{CHNO} \bullet \mathrm{CHOS}$
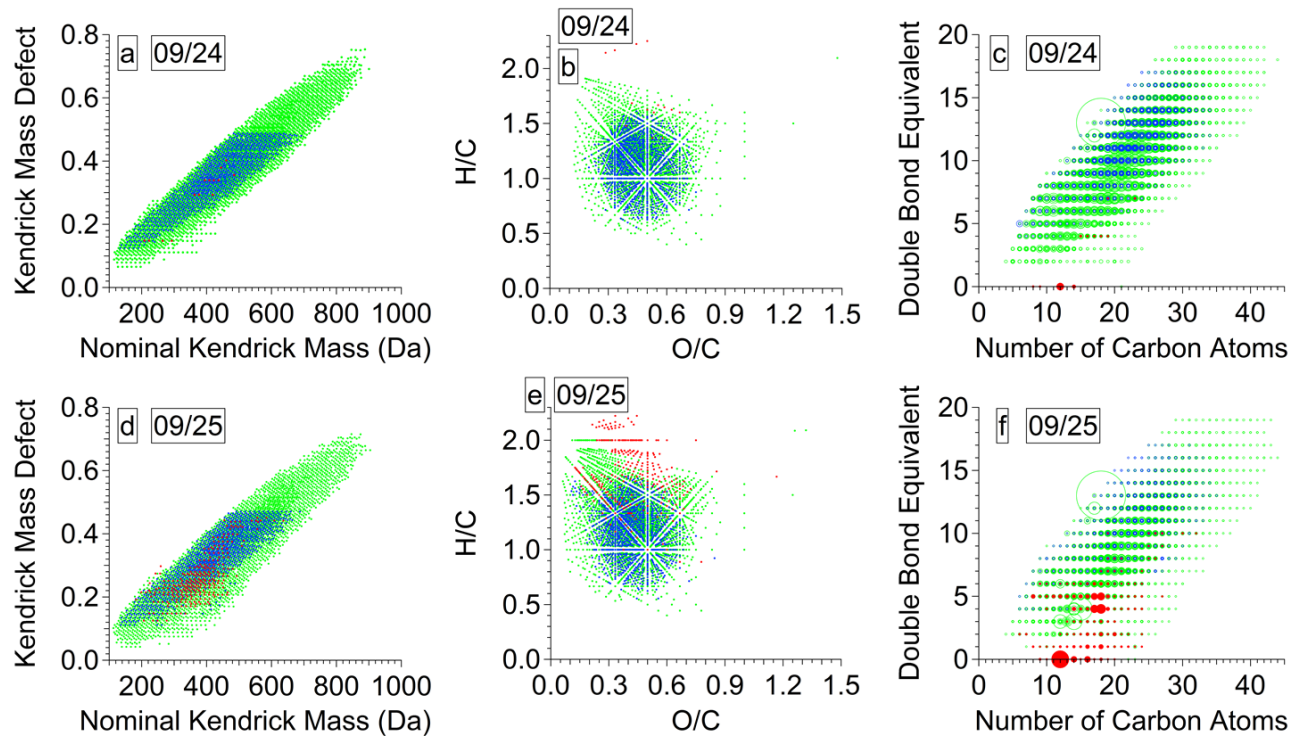

Figure 6. Characterization of all monoisotopic molecular assignments detected in WSOM of 9/24 (top panels) and 9/25 (bottom panels). Kendrick mass defect vs. nominal Kendrick mass for 9/24 (a) and 9/25 (d). van Krevelen diagrams for 9/24 (b) and 9/25 (e). Double bond equivalents vs. number of carbon atoms for 9/24 (c) and 9/25 (f). The size of markers in (c) and (f) denotes relative abundance. Examples of details in all three types of graphical representations are given in the Supplement (Fig. S9).

Table 3. Chemical characterization of the molecular assignments detected in selected studies. All values are average (arithmetic mean).

\begin{tabular}{|c|c|c|c|c|c|c|c|c|c|}
\hline Sample name & Sample type & Measurement site & $\mathrm{O} / \mathrm{C}$ & $\mathrm{H} / \mathrm{C}$ & $\mathrm{OM} / \mathrm{OC}$ & DBE & $\mathrm{DBE} / \mathrm{C}$ & MW & Reference \\
\hline Pico 9/24 & Aerosol & Free troposphere & 0.46 & 1.17 & 1.73 & 10.7 & 0.47 & 478 & This study \\
\hline Pico 9/25 & Aerosol & Free troposphere & 0.42 & 1.28 & 1.67 & 9.4 & 0.42 & 462 & \\
\hline Storm Peak Lab S4SXA & Aerosol & Remote & 0.53 & 1.48 & 1.91 & 6.2 & 0.34 & 414 & Mazzoleni et al. (2012) \\
\hline Millbrook, $\mathrm{NY}^{1}$ & Aerosol & Rural & 0.32 & 1.46 & 1.60 & 6.30 & 0.33 & 366 & Wozniak et al. (2008) \\
\hline Harcum, $\mathrm{VA}^{1}$ & Aerosol & Rural & 0.28 & 1.37 & 1.54 & 7.45 & 0.38 & 360 & \\
\hline $\begin{array}{l}\text { K-Puszta } 2004 \\
(\mathrm{KP} 2004)^{2}\end{array}$ & Aerosol & Rural & 0.48 & 1.40 & 1.84 & 7.36 & 0.37 & 408 & $\begin{array}{l}\text { Schmitt-Kopplin et } \\
\text { al. (2010) }\end{array}$ \\
\hline $\begin{array}{l}\text { K-Puszta } 2005 \\
(\mathrm{KP} 2005)^{2}\end{array}$ & Aerosol & Rural & 0.39 & 1.22 & 1.69 & 10.1 & 0.46 & 430 & \\
\hline Pearl River Delta, China & Aerosol & $\begin{array}{l}\text { Urban, Suburban, Ru- } \\
\text { ral, Regional }\end{array}$ & 0.46 & 1.34 & 1.85 & 5.3 & 0.45 & 265 & Lin et al. (2012a) \\
\hline Atlantic Ocean ${ }^{3}$ & Aerosol & $\begin{array}{l}\text { Marine } \\
\text { layer }\end{array}$ & 0.35 & 1.59 & 1.67 & 4.37 & 0.28 & 317 & $\begin{array}{l}\text { Schmitt-Kopplin et } \\
\text { al. (2012) }\end{array}$ \\
\hline $\begin{array}{l}\text { North Atlantic Ocean - } \\
\mathrm{All}^{4}\end{array}$ & Aerosol & boundary & 0.42 & 1.49 & 1.74 & 6.76 & 0.32 & 445 & Wozniak et al. (2014) \\
\hline $\begin{array}{l}\text { North Atlantic Ocean - } \\
\text { Aged Marine }\end{array}$ & Aerosol & boundary & 0.36 & 1.56 & 1.70 & 5.88 & 0.28 & 423 & \\
\hline Storm Peak Lab CW1 & Cloud water & Remote & 0.62 & 1.46 & 2.08 & 6.3 & 0.38 & 402 & Zhao et al. (2013) \\
\hline Storm Peak Lab CW2 & Cloud water & Remote & 0.61 & 1.46 & 2.06 & 6.3 & 0.38 & 400 & \\
\hline Fresno fog & Fog water & Rural & 0.43 & 1.39 & 1.77 & 5.6 & 0.40 & 289 & Mazzoleni et al. (2010) \\
\hline $\begin{array}{l}\text { Camden and Pinelands, } \\
\mathrm{NJ}^{5}\end{array}$ & Rainwater & Urban impacted & 1.02 & 1.49 & 2.73 & 3.24 & 0.44 & 220 & Altieri et al. $(2009 a, b)$ \\
\hline
\end{tabular}



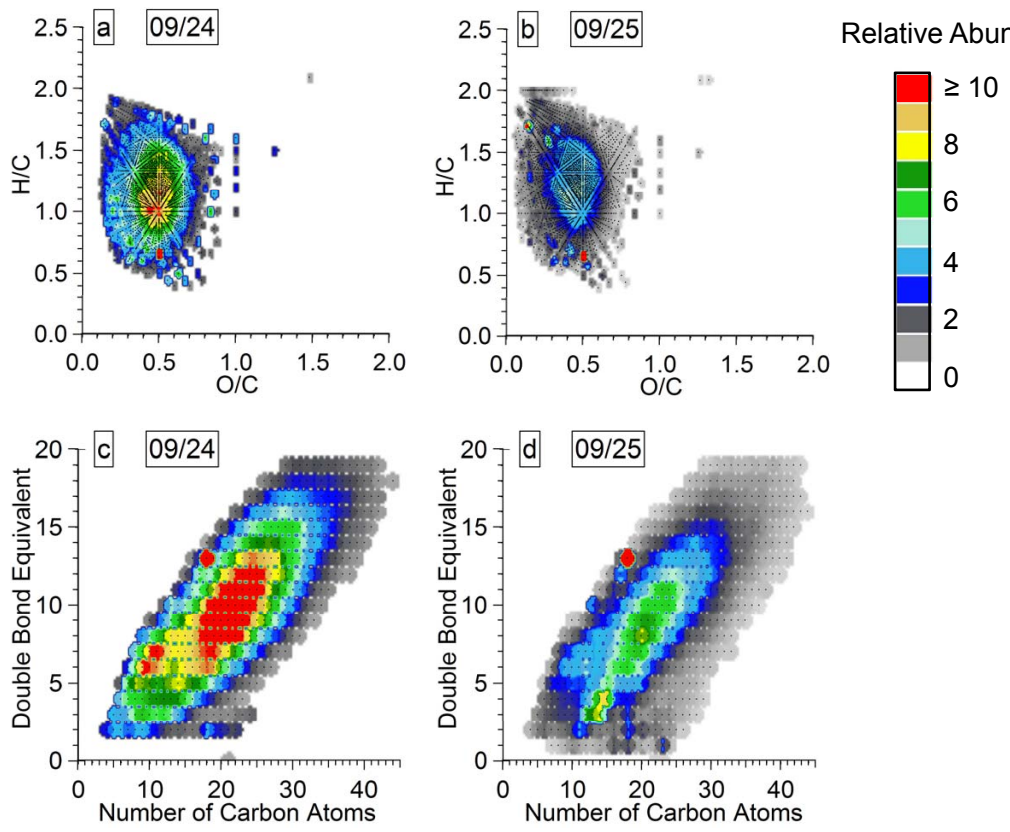

Figure 7. CHO isoabundance van Krevelen diagrams of 9/24 (a) and 9/25 (b) with all detected individual ions shown as dots to facilitate visualization of $\mathrm{CH}_{2}$ homologous series. Also shown are the double bond equivalents vs. the number of carbon atoms of the $9 / 24$ (c) and 9/25 (d) for the CHO group with symbol colour representing the relative abundance.

abundance of the overlapped species in the van Krevelen diagram depicted with a color scale. Overall, the range of observed $\mathrm{O} / \mathrm{C}$ ratios is $0.1-1.5$ and the range for $\mathrm{H} / \mathrm{C}$ ratios was $0.4-2.2$. The highest relative abundance species in $9 / 24$ were near $\mathrm{O} / \mathrm{C} \sim 0.5$ and $\mathrm{H} / \mathrm{C} \sim 1.1$ and those in $9 / 25$ were near $\mathrm{O} / \mathrm{C} \sim 0.4$ and $\mathrm{H} / \mathrm{C} \sim 1.2$. There were eight low relative abundance $(<3 \%)$ molecular assignments with an $\mathrm{O} / \mathrm{C} \geq 1$ in each sample. Both samples had a wide distribution of elemental ratios around the maximum in the van Krevelen diagrams (Table 3). The distribution of elemental ratios for the $\mathrm{CHO}$ molecular assignments in this study was similar to the aerosol reported by Mazzoleni et al. (2012) and narrower than the cloud water values reported by Zhao et al. (2013), both of which were measured at the Storm Peak Laboratory. This is consistent with the observed lower average values of $\mathrm{O} / \mathrm{C}$ and $\mathrm{H} / \mathrm{C}$ in this study $(\sim 0.44$ and 1.22$)$ compared to that of Mazzoleni et al. (2012) (0.47 and 1.42) and Zhao et al. (2013) (0.54 and 1.42).

The DBE of the CHO molecular assignments for PMO samples (Fig. 7c-d) spanned a wide range of values (0-19) and increased with the carbon number. The average DBE values for $9 / 24$ and $9 / 25$ were 10.8 and 9.8 and much higher than values of $\sim 6$ observed in WSOM studies of continental samples (Mazzoleni et al., 2012; Lin et al., 2012a; Zhao et al., 2013), which indicates they were less saturated (Table 3). Another indicator of molecular saturation for high molecular weight species, such as those found in the Pico aerosol, is the carbon-normalized DBE (DBE / C) (Hockaday et al., 2006; detailed explanation is in the Supplement).
The average DBE / C values of the CHO group for 9/24 and $9 / 25$ were 0.46 and 0.41 (Table 2), confirming the lower degree of saturation compared to Mazzoleni et al. (2012) and Zhao et al. (2013) (DBE / C values for CHO group assignments were 0.37 and 0.35). However, nearly all of the $\mathrm{CHO}$ molecular assignments were below the aromaticity criteria of DBE /C $\geq 0.7$ (95 and $97 \%$ for $9 / 24$ and $9 / 25$ ), indicating an overall lack of aromaticity. The $\mathrm{CHO}$ species were equally distributed among the entire range of DBE values, with the highest relative abundance species in 9/24 and 9/25 found in the ranges of DBE 5-14 and 3-14. The high relative abundance compounds (relative abundance $\geq 10 \%$ ) of $9 / 24$ had 7-30 carbon atoms and the highest relative abundance compounds (relative abundance $\geq 20 \%$ ) had molecular assignments with 17-24 carbon atoms (Fig. 7c). DBE values of 9/25 follow a similar pattern (Fig. 7d) and its high relative abundance $\mathrm{CHO}$ compounds had 8-31 carbon atoms (relative abundance $\geq 5 \%$ ), with the highest relative abundance compounds (relative abundance $\geq 10 \%$ ) among molecular assignments having 12-26 carbon atoms. Clearly, the highest relative abundance $\mathrm{CHO}$ species of $9 / 25$ had a wider distribution of DBE values than those on $9 / 24$. The weighted $\mathrm{O} / \mathrm{C}$ ratios of 0.47 and 0.43 for the CHO groups (Table 2) of 9/24 and 9/25 were similar to those observed for other samples collected at the Storm Peak Laboratory, a high-altitude observatory near Steamboat Springs, CO, USA. Mazzoleni et al. (2012) reported a value of 0.48 for aerosol and Zhao et al. (2013) reported a value of 0.47 for cloud water, both collected at the Storm Peak Laboratory. The weighted H / C 

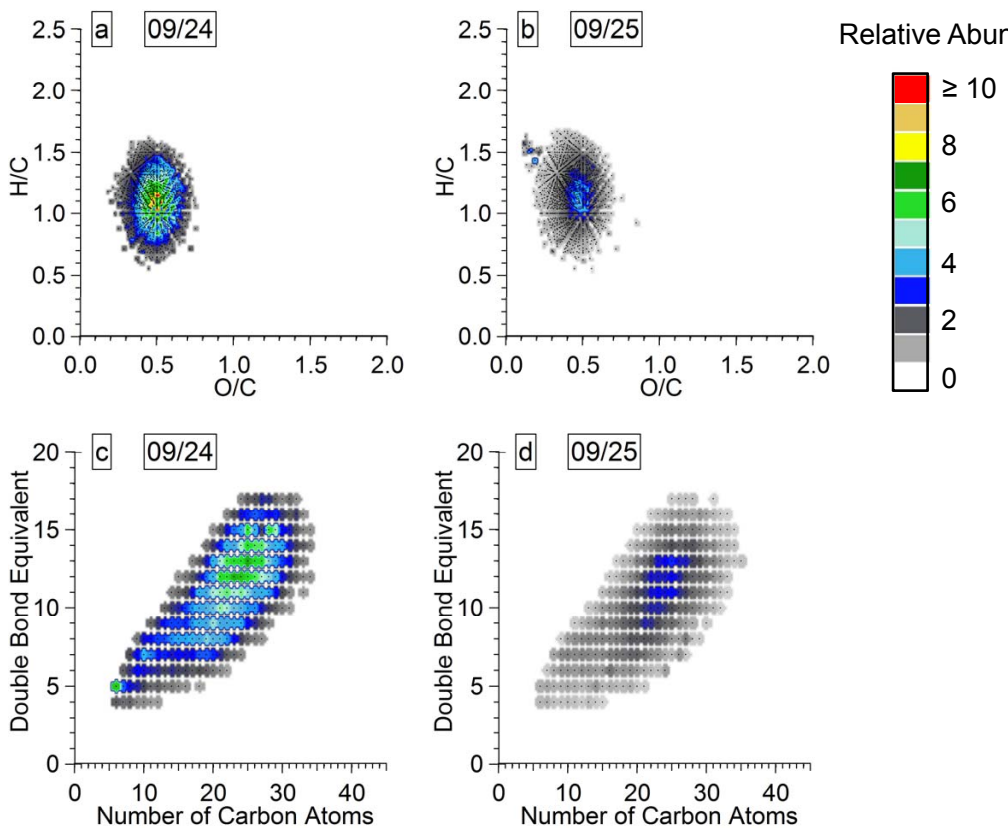

Figure 8. CHNO isoabundance van Krevelen diagrams of 9/24 (a) and 9/25 (b) with all detected individual ions shown as dots to facilitate visualization of $\mathrm{CH}_{2}$ homologous series. Also shown are the double bond equivalents vs. the number of carbon atoms of the $9 / 24$ (c) and $9 / 25$ (d) for the CHNO group with symbol colour representing the relative abundance.

ratios for $9 / 24$ and $9 / 25$ observed in this study were 1.17 and 1.26 , which is lower than values of $\sim 1.5$ previously reported for WSOM samples of aerosol (Wozniak et al., 2008; Mazzoleni et al., 2012), cloud water (Zhao et al., 2013), fog water (Mazzoleni et al., 2010), and rainwater (Altieri et al., 2009a) (Table 3). The O/C ratios of PMO aerosol are consistent with those reported for aged biomass burning aerosol measured by an Aerodyne Aerosol Mass Spectrometer (AMS) (Aiken et al., 2008). Ultrahigh resolution MS elemental ratios have been found to both agree (Bateman et al., 2012) and disagree (O'Brien et al., 2013) with the ones measured by AMS, although a direct comparison of elemental ratios measured by FT-ICR MS and AMS has not yet been reported.

Numerous molecular formulas matching biomass burning markers (Simoneit, 2002) were observed in PMO samples. Burning products of biopolymers such as cellulose, lignin, and lignans can represent major amounts of $\mathrm{OA}$ originating from biomass burning. Levoglucosan is one of the main particle-phase markers of cellulose decomposition and its molecular formula $\left(\mathrm{C}_{6} \mathrm{H}_{10} \mathrm{O}_{5}\right)$ was observed in $9 / 24$ and $9 / 25$ with relative abundances of 3.4 and $0.6 \%$. Note this formula could come from other compounds with the same molecular formula such as galactosan and mannosan (Simoneit et al., 2001). In both samples, we also observed formulas that could be lignin pyrolysis products such as vanillic acid $\left(\mathrm{C}_{8} \mathrm{H}_{8} \mathrm{O}_{4}\right.$; relative abundance $=11.1$ and $2.0 \%)$, syringaldehyde $\left(\mathrm{C}_{9} \mathrm{H}_{10} \mathrm{O}_{4}\right.$; relative abundance $=9.2$ and $2.0 \%)$ and syringic acid $\left(\mathrm{C}_{9} \mathrm{H}_{10} \mathrm{O}_{5}\right.$; relative abundance $=7.3$ and $1.4 \%$ ). In all of the cases, higher relative abundances were observed in the mass spectra of $9 / 24$. Burning of lignin produces phenol $\left(\mathrm{C}_{6} \mathrm{H}_{6} \mathrm{O}\right)$, guaiacol (2-methoxyphenol; $\left.\mathrm{C}_{7} \mathrm{H}_{8} \mathrm{O}_{2}\right)$ and syringol $(1,3-$ dimethoxyphenol; $\mathrm{C}_{8} \mathrm{H}_{10} \mathrm{O}_{3}$ ) (Simoneit, 2002). Phenols can also be formed in the atmosphere by oxidation of aromatics and HULIS (Graber and Rudich, 2006). These molecular formulas were found in $9 / 24$ and $9 / 25$ with higher relative abundance on $9 / 24$, including phenol (relative abundance $=3.5$ and $0.6 \%$ ), guaiacol (relative abundance $=2.8$ and $0.7 \%$ ), and syringol (relative abundance $=7.0$ and $1.5 \%$ ). Sun et al. (2010) observed that aqueous-phase oxidation of guaiacol and syringol yields a substantial fraction of dimers and higher oligomers, with key dimer markers identified as $\mathrm{C}_{16} \mathrm{H}_{18} \mathrm{O}_{6}$ and $\mathrm{C}_{14} \mathrm{H}_{14} \mathrm{O}_{4}$. Their results indicated that fog and cloud processing of phenolic species could be an important mechanism for the production of low-volatility SOA. The dimer markers $\mathrm{C}_{16} \mathrm{H}_{18} \mathrm{O}_{6}$ and $\mathrm{C}_{14} \mathrm{H}_{14} \mathrm{O}_{4}$ were also present in PMO WSOM with high relative abundance (for 9/24: relative abundance $=14.1$ and $8.1 \%$; for $9 / 25$ : relative abundance $=4.4$ and $2.4 \%$ ).

\subsubsection{Characteristics of the CHNO molecular formulas}

CHNO species had a narrow distribution of elemental ratios in the isoabundance van Krevelen diagram (Fig. 8a-b). For 9/24, O / C and $\mathrm{H} / \mathrm{C}$ ratios spanned the range of 0.2 0.75 and $0.6-1.6$ with higher relative abundance molecular formulas (relative abundance $\geq 4 \%$ ) in the range of $0.3-0.6$ and $0.8-1.4$. Similar values were observed for $9 / 25$. Average $\mathrm{O} / \mathrm{C}$ ratios for $9 / 24$ and $9 / 25$ were 0.45 and 0.42 and 
average $\mathrm{H} / \mathrm{C}$ ratios were 1.14 and 1.18. A comparison of the distribution of the $\mathrm{CHO}$ and $\mathrm{CHNO}$ molecular assignments in the van Krevelen diagrams (Figs. 7 and 8, respectively) shows that they were found in similar ranges. The average elemental ratios for $\mathrm{CHO}$ and $\mathrm{CHNO}$ species were similar for both samples, which is a possible indication of the same emission sources and transformational processes. The $\mathrm{O} / \mathrm{C}$ ratios of the CHNO compounds were lower than those previously observed for continental aerosol (0.57; Mazzoleni et al., 2012) and cloud water (0.72; Zhao et al., 2013). Similarly, CHNO molecular species detected in continental rainwater (Altieri et al., 2009a, b) were more oxygenated $(\mathrm{O} / \mathrm{C}=1.6)$ and saturated $(\mathrm{H} / \mathrm{C}=1.9)$ than PMO aerosol WSOM. Rural aerosol collected at a ground site had elemental ratios similar to those reported here and might have been influenced by biomass burning as indicated by the detection of marker species such as lignin and nitro-aromatics (Wozniak et al., 2008). Likewise, Schmitt-Kopplin et al. (2010) reported similar elemental ratios for an aerosol sample collected during a biomass burning event (Table 3). They observed a high abundance of CHNO species attributed to aromatic acids, lignins, and SOA formation. The same work reports mass resolved H / C diagrams for biomass burning aerosol (SchmittKopplin et al., 2010), which had a strong resemblance to those reported here for both PMO samples (Fig. S8a-b). A significant contribution of CHNO compounds was observed in aerosol collected in the Pearl River Delta region in China and was attributed to biomass burning HULIS and photochemically produced SOA (Lin et al., 2012a). The CHNO molecular assignments in their study had similar elemental ratios $(\mathrm{O} / \mathrm{C}=0.41$ and $\mathrm{H} / \mathrm{C}=1.15)$ and an $\mathrm{OM} / \mathrm{OC}$ ratio (1.80) as those described here, and their composition was explained by the presence of nitro or nitrate groups. Similar to the findings of Lin et al. (2012a), we observed high O / N ratios ( $\sim 8$ on average) and nearly all CHNO compounds had $\mathrm{O} / \mathrm{N} \geq 3$, indicating that nitrogen was in the form of organic nitrate $\left(-\mathrm{ONO}_{2}\right)$ or nitro $\left(-\mathrm{NO}_{2}\right)$ groups with excess oxygen forming additional oxygenated groups.

The DBE values for the CHNO molecular assignments covered a wide range from 4 to 17 for both samples (Fig. 8cd). This range of DBE values represented CHNO species with carbon numbers up to 35 . As expected, the DBE increased with the increase in the number of carbon atoms. CHNO molecular assignments with high relative abundance in 9/24 had 16-30 carbon atoms with DBE values in the range of 8-16. The most abundant CHNO species were those with 19-25 carbon atoms and DBE in the range of 1012. Similar characteristics were observed in $9 / 25$. Finally, CHNO molecular assignments in $9 / 24$ and 9/25 had average DBE of 10.3 and 9.8, and DBE / C ones of 0.51 and 0.49 (Table 2), with nearly all molecular formula with DBE / C below the aromaticity criteria of 0.7 (92 and $94 \%$ ). Similar to the CHO compounds, the DBE values of CHNO compounds in this study were much higher than those observed for continental WSOM samples in other studies.
In both PMO aerosol WSOM samples, we observed 1 or 2 nitrogen atoms $\left(\mathrm{N}_{1}\right.$ or $\mathrm{N}_{2}$ molecular formulas, respectively) per CHNO molecular formula, although we allowed up to 3 nitrogen atoms per formula assignment. In both samples, $\mathrm{N}_{1}$ molecular formulas make up the majority of $\mathrm{CHNO}$ species $\left(91 \%\right.$ ), while $\mathrm{N}_{2}$ molecular formulas represent only $9 \%$. In order to better understand this, we divided molecular formulas according to their nitrogen and oxygen content. In this way, a distribution of the subclasses is observed. This distribution was very similar for the two samples (Fig. S10): $\mathrm{N}_{1}$ and $\mathrm{N}_{2}$ CHNO molecular assignments had up to 14 and 13 , respectively, $\mathrm{O}$ atoms. For the $\mathrm{N}_{1}$ species, the trend of the sum of relative abundance vs. oxygen number (Fig. S10) uniformly increased to its maximum of $\sim \mathrm{N}_{1} \mathrm{O}_{11}$ after which it dropped off sharply. Nearly all molecular formulas in the $\mathrm{N}_{1}$ and $\mathrm{N}_{2}$ classes were enriched in oxygen (high $\mathrm{O} / \mathrm{N}$ ratio), indicating the likely presence of organic nitrate or nitro groups.

\subsubsection{Characteristics of the CHOS molecular formulas}

A small number of CHOS molecular assignments $(N=14$ and 289 for $9 / 24$ and $9 / 25$ ) was observed and the majority of them had low relative abundance. For $9 / 24$, CHOS molecular assignments had average $\mathrm{O} / \mathrm{C}$ and $\mathrm{H} / \mathrm{C}$ ratios of 0.5 and 1.75, respectively (Fig. 9a). The $\mathrm{H} / \mathrm{C}$ ratio was significantly higher than those observed for $\mathrm{CHO}$ and CHNO compounds, indicating a higher degree of saturation. Relatively high saturation of $9 / 24$ CHOS species was confirmed by their significantly lower average DBE (Fig. 9c) and DBE / C value of 0.20 (Table 2). Furthermore, no molecular assignments in 9/24 (as well as in 9/25) were found above the DBE / C aromaticity threshold of 0.7. The range of DBE values for $9 / 24$ is $0-7$, with only three discrete DBE values $(0,4$ and 7$)$. Except for three molecular assignments $\left(\mathrm{C}_{23} \mathrm{H}_{34} \mathrm{O}_{9} \mathrm{~S}, \mathrm{C}_{19} \mathrm{H}_{26} \mathrm{O}_{10} \mathrm{~S}\right.$, and $\left.\mathrm{C}_{19} \mathrm{H}_{26} \mathrm{O}_{11} \mathrm{~S}\right)$, most of the CHOS compounds in $9 / 24$ can be grouped into three $\mathrm{CH}_{2}$ homologous series in the van Krevelen diagram $\left(\mathrm{C}_{7} \mathrm{H}_{16}\left(\mathrm{CH}_{2}\right)_{1-2,5,7} \mathrm{O}_{4} \mathrm{~S}, \mathrm{C}_{14} \mathrm{H}_{22}\left(\mathrm{CH}_{2}\right)_{1-4} \mathrm{O}_{10} \mathrm{~S}\right.$, and $\left.\mathrm{C}_{14} \mathrm{H}_{22}\left(\mathrm{CH}_{2}\right)_{1-2,5} \mathrm{O}_{8} \mathrm{~S}\right)$. We note the presence of a very low number of CHOS assignments in 9/24.

The $9 / 25$ species had a substantially higher number of CHOS assignments $(N=289)$. The isoabundance van Krevelen diagram (Fig. 9b) shows that CHOS species had a similar average $\mathrm{O} / \mathrm{C}$ ratio and higher $\mathrm{H} / \mathrm{C}$ ratio than the $\mathrm{CHO}$ and $\mathrm{CHNO}$ species. The range of $\mathrm{O} / \mathrm{C}$ ratios for the CHOS species in $9 / 24$ was $0.1-1.2$ and the $\mathrm{H} / \mathrm{C}$ ratio range was $0.9-2.2$. The average elemental ratios were $\mathrm{O} / \mathrm{C}=0.41$ and $\mathrm{H} / \mathrm{C}=1.7$. The elemental ratios did not show a narrow distribution in the van Krevelen diagram (Fig. 9b). Rather, we observed several groups of compounds following straight lines of $\mathrm{CH}_{2}$ homologous series. The highest relative abundance corresponded to a fully saturated formula $\left(\mathrm{C}_{12} \mathrm{H}_{26} \mathrm{O}_{4} \mathrm{~S}\right)$, which is likely an organosulfate species. The higher relative abundance molecular formulas were found 

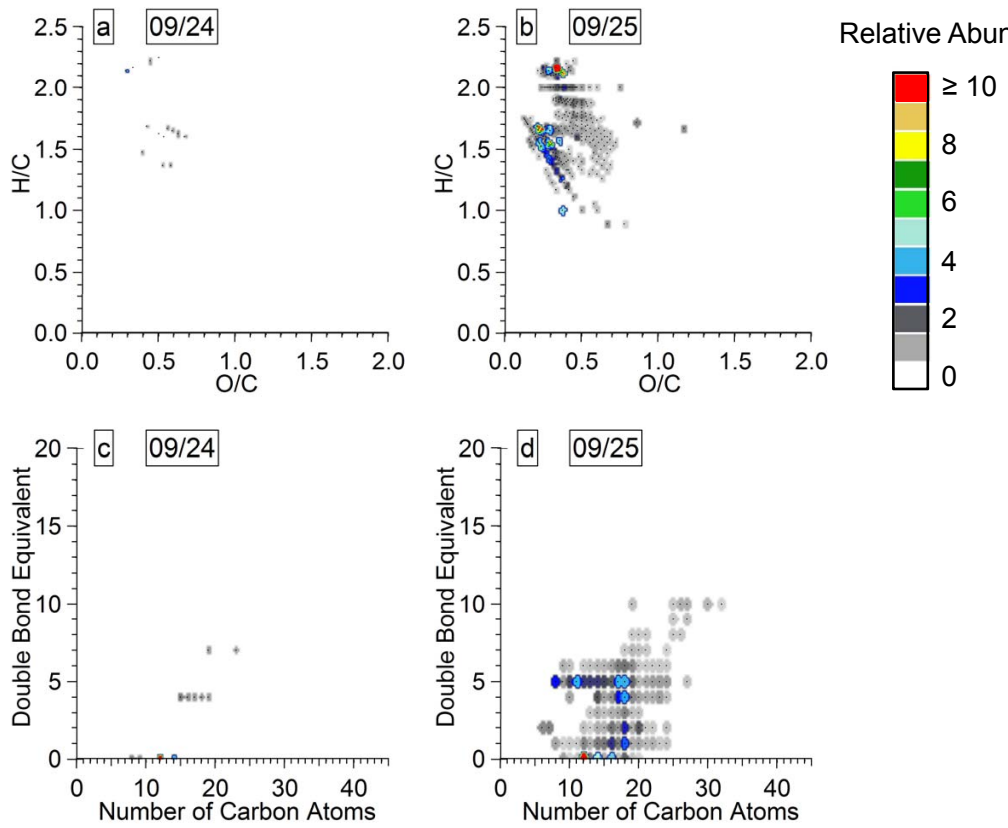

Figure 9. CHOS group species isoabundance van Krevelen diagram for 9/24 (a) and 9/25 (b) with all detected individual ions shown as dots to facilitate visualization of $\mathrm{CH}_{2}$ homologous series. Also shown are the double bond equivalents $v s$. the number of carbon atoms of the 9/24 (c) and 9/25 (d) for the CHOS group with symbol colour representing the relative abundance.

around the elemental ratios of $\mathrm{O} / \mathrm{C}=0.25$ and $\mathrm{H} / \mathrm{C}=1.6$, indicating a low degree of oxygenation and a high degree of saturation. Much lower DBE and DBE / C values than those observed for $\mathrm{CHO}$ and $\mathrm{CHNO}$ compounds were consistent with the higher saturation of CHOS species (Fig. 9d and Table 2). Molecular assignments with the highest relative abundance had a DBE of 0 and several species with high relative abundance were clustered around DBE values of 4 and 5 . Figure $\mathrm{S} 11$ shows that the highest relative abundance species had four oxygen atoms and the relative abundance gradually decreased towards the maximum oxygen content of 13 oxygen atoms. The frequency distribution of the number of CHOS molecular assignments was similar to the oxygen content with a slight shift where the majority of species were found in $\mathrm{O}_{5} \mathrm{~S}$ and $\mathrm{O}_{6} \mathrm{~S}$ subclasses $(N=48$ and 52$)$.

Low DBE values and high $\mathrm{O} / \mathrm{S}$ ratios indicate the presence of organosulfates similar to previous findings in samples of aerosol (Mazzoleni et al., 2012) and cloud water (Zhao et al., 2013). Consistent with Zhao et al. (2013), CHOS species were not narrowly distributed in the van Krevelen diagram (Fig. 9a-b) as observed for $\mathrm{CHO}$ (Fig. 7a-b) and CHNO (Fig. 8a-b). Similar to the previous study of Schmitt-Kopplin et al. (2010), we noted the presence of several groups of CHOS species in the regions of the van Krevelen diagram attributed to fatty acids, oxidized terpenoids, and aromatic acids from lignins. Those studies also found a group of CHOS species with low saturation and $\mathrm{O} / \mathrm{C}$ ratio that was attributed to aromatic moieties, which we did not observe here. The presence of organosulfates in fog water was con- firmed by tandem mass spectrometry (MS / MS) analysis (LeClair et al., 2012). Lin et al. (2012a) identified CHOS species in biomass burning aerosol with similar DBE values and higher $\mathrm{O} / \mathrm{C}$ ratios compared to this study and attributed them to HULIS. Another study detected HULIS organosulfates (Lin et al., 2012b) and noted very few CHOS species in regional background aerosol collected at a mountaintop site. The lack of CHOS species was attributed to biomass burning and anthropogenic aerosol that were not sufficiently acidic to catalyze formation of organosulfates. We found a similar low number of CHOS species in WSOM collected at PMO. Similarly, Schmitt-Kopplin et al. (2010) observed a lower number frequency of $\mathrm{CHOS}$ compounds than $\mathrm{CHO}$ and $\mathrm{CHNO}$ in biomass burning aerosol. Conversely, our finding of a low number of sulfur-containing species in longrange transported aerosol is in contrast to a recent study of urban aerosol in Los Angeles and Shanghai, which was dominated by organosulfates (Tao et al., 2014).

Oceanic marine algae produce dimethylsulfoniopropionate (DMSP), which is degraded by marine bacteria to dimethylsulfide (DMS). Once DMS is in the atmosphere, it is rapidly oxidized to aerosol sulfate via methanesulfonic acid and sulfur dioxide (Yoch, 2002). It is well documented that organosulfates can originate from the oxidation of marine biomass (O’Dowd et al., 1997; Rinaldi et al., 2010; Fu et al., 2011; Schmale et al., 2013). Non-sea-salt sulfate species in marine aerosol have previously been found and attributed to the degradation of marine primary emissions (e.g., Cavalli et al., 2004). Furthermore, the degradation products of marine 


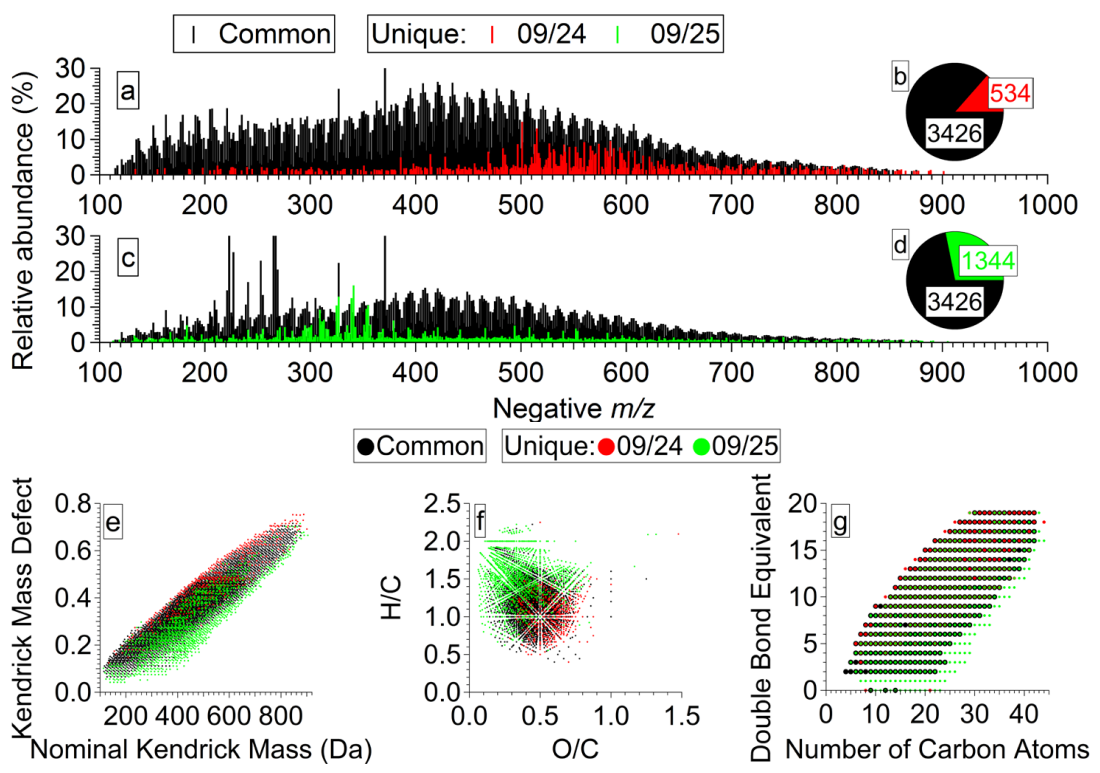

Figure 10. Mass spectra of $9 / 24$ (a) and $9 / 25$ (c) with common ions detected in both samples and ions unique for each sample. Pie charts indicate number fraction of common and unique molecular assignments detected in 9/24 (b) and 9/25 (d); the exact numbers of common and unique assignment are given. Bottom panels: Comparison of common and unique ions detected in PMO samples in Kendrick plot (e), van Krevelen diagram (f), and double bond equivalents vs. the number of carbon atoms (g).

flora such as methanesulfonic acid have been shown to peak in summer months and produce aliphatic organic species with low oxygenation (Cavalli et al., 2004; Ovadnevaite et al., 2014). Nevertheless, reports of molecular-level speciation of organosulfates in marine aerosol are sparse. Recently, Claeys et al. (2010) determined that the members of the $\mathrm{C}_{8} \mathrm{H}_{16}\left(\mathrm{CH}_{2}\right)_{1-5} \mathrm{O}_{6} \mathrm{~S}$ homologous series are the organosulfate markers of marine SOA formed from the oxidation and sulfation of algal and bacterial fatty acids residue. We identified in $9 / 25$ all of those molecular species except one $\left(\mathrm{C}_{9} \mathrm{H}_{18} \mathrm{O}_{6} \mathrm{~S}\right)$. Moreover, the $\mathrm{O}_{6} \mathrm{~S}$ class was the most abundant class in the 9/25 CHOS group and had the longest CHOS homologous series $\left(\mathrm{C}_{7} \mathrm{H}_{14}\left(\mathrm{CH}_{2}\right)_{1,3-17} \mathrm{O}_{6} \mathrm{~S}\right)$, consistent with Claeys et al. (2010). Many other CHOS group homologous series were observed in $9 / 25$ with long carbon chains (up to $\mathrm{C}_{32}$ ) and high oxygen content (up to $\mathrm{O}_{13}$ ), consistent with the oxidation and sulfonation of primary marine biomass and subsequent additional processing during oxidative aging. Recent study of aerosol collected on a research vessel in the North Atlantic Ocean detected 246 CHOS species in aged marine aerosol, a number of CHOS species comparable to our study (Wozniak et al., 2014; "Aged marine" PCA group from their study is given in Table 3). Consistent with Claeys et al. (2010), Wozniak et al. (2014) attributed the observed CHOS species to organosulfate markers of marine aerosol degradation albeit with longer carbon chains. The CHOS species reported in Wozniak et al. (2014) have similar chemical characteristics to those reported here (magnitudeweighted average $\mathrm{O} / \mathrm{C}=0.36$ and $\mathrm{H} / \mathrm{C}=1.57$ ).

\subsubsection{Comparison of the Pico Mountain Observatory aerosol samples}

Overall, the molecular formulas assigned to $9 / 24$ and $9 / 25$ were quite similar. A total of 3426 molecular formulas were common to both of the samples ("common" molecular formulas), and they spanned the entire $m / z$ range (Fig. 10a-d). Molecular formulas detected in only one sample ("unique" molecular formulas) were fewer in number $(N=541$ and 1372 for $9 / 24$ and 9/25). Most of the unique molecular formulas had low relative abundances. The highest relative abundance species in $9 / 24$ were found in the range of $m / z 450-700$, while for $9 / 25$ this range was $250-400$. Similarly, the Kendrick plot analysis showed the unique assignments in 9/24 had homologous series preferentially extending to lower masses and those in $9 / 25$ tended to form homologous series extending to higher masses (Fig. 10e).

The two WSOM samples were characterized by similar but not identical bulk properties. The average $\mathrm{O} / \mathrm{C}$ ratio of $9 / 24$ was slightly higher than $9 / 25$ (0.46 vs. 0.42$)$, indicating more oxygenation. In our previous study of a case similar to $9 / 24$ that included substantial plume lofting to the middle free troposphere (Zhang et al., 2014), coupled GEOSChem and FLEXPART simulations suggested that similar transport patterns are capable of carrying more PAN in polluted plumes than non-lifted transport. The additional PAN is thus able to thermally decompose, resulting in a significant $\mathrm{NO}_{x}$ release and subsequent ozone production during plume subsidence. This mechanism may have provided a second opportunity for efficient oxidation of the $9 / 24$ aerosol. In 
contrast, $\mathrm{NO}_{x}$ and ozone production potential would quickly diminish in the marine boundary layer as shown by Zhang et al. (2014). In addition, air masses that transported the aerosol collected in $9 / 25$ underwent longer transport times at substantially lower altitudes in cleaner marine atmosphere (the averaged residence time spent over the North Atlantic Ocean for the retroplumes of $9 / 25$ was 9.5 days vs. 7 days for $9 / 24$ ). Processing of compounds found in primary marine emissions which did not influence 9/24 air masses would also explain the higher number of unique molecular assignments found in $9 / 25$.

The average $\mathrm{H} / \mathrm{C}$ ratio of $9 / 24$ was slightly lower than that of $9 / 25$ (1.17 vs. 1.28), indicating a lower saturation. The van Krevelen diagram in Fig. 10f that compares the two samples shows that $9 / 24$ molecular assignments had higher oxygenation (i.e., higher $\mathrm{O} / \mathrm{C}$ ) and lower saturation (i.e., lower $\mathrm{H} / \mathrm{C}$ ). A lower degree of saturation in $9 / 24$ is also supported by the higher DBE and DBE / C values (Tables 2 and 3). The same trend in elemental ratios was observed for the $\mathrm{CHO}, \mathrm{CHNO}$, and CHOS group species. The exception to this was the higher $\mathrm{H} / \mathrm{C}$ ratio of the CHOS group on 9/24, which might be due to the very low number of CHOS assignments. Approximately $70 \%$ of the molecular assignments in both samples were CHO species, and nearly all of the remaining compounds were CHNO species. Thus, the overall elemental ratio characteristics will be strongly driven by species belonging to these two groups. Note molecular formulas unique to $9 / 25$ were located in the regions of the van Krevelen diagram (Fig. 10f) assigned to fatty acids (Schmitt-Kopplin et al., 2010) consistent with more abundant marine aerosol. An enhancement of several common ions in the range of $m / z$ 200-300 was observed in 9/25 (Fig. 10c). These strong $\mathrm{CHO}$ and one CHOS ions have the following molecular formulas: $\mathrm{C}_{11} \mathrm{H}_{10} \mathrm{O}_{4}, \mathrm{C}_{10} \mathrm{H}_{10}\left(\mathrm{CH}_{2}\right)_{1-2} \mathrm{O}_{4}$, $\mathrm{C}_{12} \mathrm{H}_{20}\left(\mathrm{CH}_{2}\right)_{1-2} \mathrm{O}_{2}, \quad \mathrm{C}_{12} \mathrm{H}_{20} \mathrm{O}_{3}, \quad \mathrm{C}_{11} \mathrm{H}_{18}\left(\mathrm{CH}_{2}\right)_{1-2} \mathrm{O}_{4}$, $\mathrm{C}_{12} \mathrm{H}_{18}\left(\mathrm{CH}_{2}\right)_{1-3} \mathrm{O}_{4}, \mathrm{C}_{12} \mathrm{H}_{18}\left(\mathrm{CH}_{2}\right)_{1-2} \mathrm{O}_{4}$, and $\mathrm{C}_{12} \mathrm{H}_{26} \mathrm{O}_{4} \mathrm{~S}$. With lower oxygenation and higher saturation than other $\mathrm{CHO}$ compounds detected in this study (their average values \pm standard deviation were $\mathrm{O} / \mathrm{C}=0.30 \pm 0.08$, $\mathrm{H} / \mathrm{C}=1.49 \pm 0.26, \mathrm{DBE}=4.15 \pm 1.34$, and $\mathrm{DBE} / \mathrm{C}=$ $0.33 \pm 0.14$ ), the enhancement of these species in $9 / 25$ over $9 / 24$ might be an additional indication of species such as fatty acids and thus marine aerosol contribution to 9/25.

The average DBE values (and DBE / C in the parenthesis) of 9/24 and 9/25 were 10.7 (0.47) and 9.4 (0.42) (Fig. 10g), and these values were similar to the average DBE found in the $\mathrm{CHO}$ and $\mathrm{CHNO}$ groups (Tables 2 and 3). Much lower values were found for the CHOS group, consistent with a higher saturation of these species as noted previously. Figure $10 \mathrm{~g}$ clearly showed that the unique molecular assignments detected in 9/24 had higher DBE values, while those detected during $9 / 25$ had a uniform distribution among all of the observed DBE values.

\section{Conclusions}

Our findings confirm the dominance of OA in the total aerosol mass fraction of remote atmospheres, followed by sulfate and nitrate aerosol. The molecular characterization of long-range transported aerosol provides novel insights on the aerosol properties in remote regions and at high-altitude observatories. The subtle differences in the composition of the two samples were attributed to the sampling of somewhat different air masses. The FLEXPART simulations indicated that air masses intercepted during the measurements of 9/24 and $9 / 25$ had average plume ages of 12.4 and 14.7 days and were influenced by wildfires in North America. Specifically, the 9/24 air masses were influenced by an intense biomass burning plume, while 9/25 air masses were less polluted with some influence from the North Atlantic Ocean marine boundary layer. The air masses of $9 / 24$ had higher transport heights than those of $9 / 25$, which for $9 / 24$ might have allowed for increased production of oxidants such as ozone during their subsidence. The differences in the air masses were confirmed by changes in collocated on-line measurements of ozone, non-methane hydrocarbons (ethane and propane), black carbon mass concentration, aerosol number concentration and aerosol scattering coefficient.

Ultrahigh resolution FT-ICR MS analysis of WSOM detected approximately 4000 and 5000 monoisotopic molecular formulas in $9 / 24$ and $9 / 25$. The majority of identified compounds in both samples belong to $\mathrm{CHO}(\sim 70 \%)$ and CHNO ( $25 \%)$ elemental groups, while CHOS group compounds represented only a small number fraction. The low average $\mathrm{O} / \mathrm{C}(\sim 0.45)$ and $\mathrm{H} / \mathrm{C}(\sim 1.20)$ ratios indicate low oxygenation and saturation. The observed unsaturation of species may be a result of the biomass burning emissions, which include aerosol species more unsaturated than terpene SOA products. Similar low saturation of aged and photochemically processed aerosol, as reflected in high DBE and DBE / C values, was previously observed for biomass burning influenced samples collected in Hungary during 2005 (Schmitt-Kopplin et al., 2010, as shown in Table 3). The presence of biomass burning markers was observed with higher relative abundance for $9 / 24$, while organosulfate markers of marine aerosol were present only in the $9 / 25$. Similarly, the presence of a higher fraction of spherical particles (possibly tar balls) and a higher fraction of heavily coated soot suggests that $9 / 24$ was more highly influenced by biomass burning. The compounds in $9 / 25$ attributed to fatty acids and products of DMS oxidation support the marine origin of these WSOM.

The molecular distributions of the Pico WSOM species yield a remarkable visual uniformity in all of the graphical representations, suggesting a highly aged and processed aerosol. High molecular weight species unique for this study are likely oligomers produced by mechanisms involving aqueous-phase oxidation of biomass burning species, as previously observed in laboratory studies (Holmes and Petrucci, 
2006; Sun et al., 2010). The presence of markers characteristic for aqueous-phase processing of biomass burning aerosol suggests the biomass burning aerosol was processed by clouds and remained in the particle-phase after the evaporation of water. Similar observations of aqueous-phase processing of biomass burning aerosol leading to oligomer products were previously reported for cloud (Zhao et al., 2013) and fog water (Mazzoleni et al., 2010).

Low $\mathrm{O} / \mathrm{C}$ ratios of the PMO WSOM likely resulted from aqueous-phase oxidative reactions during the longrange transport which led to chemical transformations such as selective molecular fragmentation (Kroll et al., 2009) and an increased solubility of the species. This would create more polar molecules, which are likely preferentially removed by cloud processes yielding aerosol with a lower O/C. Another mechanism that may selectively remove highly oxidized species in very aged aerosol is photolysis, possibly leading to the fragmentation of oxidized functional groups. Both photolysis and aqueous-phase reactions eliminate small gas-phase molecules, e.g., $\mathrm{CO}, \mathrm{CO}_{2}$, formaldehyde $\left(\mathrm{CH}_{2} \mathrm{O}\right)$, and formic acid $(\mathrm{HCOOH})$ as shown in laboratory experiments (Pan et al., 2009; Sareen et al., 2013). Finally, the low $\mathrm{H} / \mathrm{C}$ and higher DBE and DBE / C values than previously observed for continental WSOM suggest a lower degree of saturation in agreement with very aged and processed aerosol after long-range transport ( $\mathrm{Ng}$ et al., 2011). Thus, we hypothesize the observed characteristics of the Pico aerosol resulted from the combination of formation and subsequent removal of highly aged and polar species as a cumulative result of oxidation, aqueous-phase processing, evaporation, and photolysis during long-range transport.

Finally, observations of very aged ambient samples analyzed by ultrahigh resolution mass spectrometry methods are sparse, which limits comparison of observations. Future research is needed to systematically characterize WSOM of different ages, sources, and transformational processes.

\section{The Supplement related to this article is available online at doi:10.5194/acp-15-5047-2015-supplement.}

Acknowledgements. This research was sponsored by the US National Science Foundation (AGS-1110059) and the US Department of Energy's Atmospheric System Research (DE-SC0006941). S. China was supported with a US National Aeronautics and Space Administration, Earth and Space Science Graduate Fellowship (NNX12AN97H). Additional support was provided by Michigan Technological University (College of Sciences and Arts; Earth, Planetary and Space Sciences Institute and the Departments of Chemistry and Physics) for equipment cost share associated with the above grants. We thank the Azores University and the Regional Government of Azores through the Regional Secretariat of the Environment and the Sea for access to the station, the Pico mountain guides Nilton Nunes and Jorge Sergio of CUME 2351
Outdoor Experience for assistance with equipment transportation to the observatory, and Melissa Soule and Elizabeth Kujawinski of the Woods Hole Oceanographic Institution (WHOI) Mass Spectrometry Facility for FT-ICR MS data acquisition (NSF OCE-0619608 and Gordon and Betty Moore Foundation). We also thank Evan Kane of the Michigan Technological University for assistance with the ion chromatography measurements, Senait Gebreeyesus of the Michigan Technological University for assistance with the OC/EC measurements, and Audra McClure-Begley of NOAA Earth System Research Laboratory for analyzing and providing Pico ozone measurements. We are grateful to P. Schmitt-Kopplin and A. Wozniak for providing the FT-ICR MS data sets for Table 3. We thank S. Madronich, Q. Zhang, and Y. Zhao for helpful discussions. Finally, we thank the three anonymous reviewers for helpful suggestions to improve the paper.

Edited by: S. A. Nizkorodov

\section{References}

Adachi, K. and Buseck, P. R.: Atmospheric tar balls from biomass burning in Mexico, J. Geophys. Res., 116, D05204, doi:10.1029/2010JD015102, 2011.

Aiken, A. C., DeCarlo, P. F., Kroll, J. H., Worsnop, D. R., Huffman, J. A., Docherty, K. S., Ulbrich, I. M., Mohr, C., Kimmel, J. R., Sueper, D., Sun, Y., Zhang, Q., Trimborn, A., Northway, M., Ziemann, P. J., Canagaratna, M. R., Onasch, T. B., Alfarra, M. R., Prevot, A. S. H., Dommen, J., Duplissy, J., Metzger, A., Baltensperger, U., and Jimenez, J. L.: O/C and OM/OC ratios of primary, secondary, and ambient organic aerosols with high resolution time-of-flight aerosol mass spectrometry, Environ. Sci. Technol., 42, 4478-4485, 2008.

Altieri, K. E., Turpin, B. J., and Seitzinger, S. P.: Oligomers, organosulfates, and nitrooxy organosulfates in rainwater identified by ultra-high resolution electrospray ionization FTICR mass spectrometry, Atmos. Chem. Phys., 9, 2533-2542, doi:10.5194/acp-9-2533-2009, 2009a.

Altieri, K. E., Turpin, B. J., and Seitzinger, S. P.: Composition of dissolved organic nitrogen in continental precipitation investigated by ultra-high resolution FT-ICR mass spectrometry, Environ. Sci. Technol., 43, 6950-6955, 2009b.

Altieri, K. E., Hastings, M. G., Peters, A. J., and Sigman, D. M.: Molecular characterization of water soluble organic nitrogen in marine rainwater by ultra-high resolution electrospray ionization mass spectrometry, Atmos. Chem. Phys., 12, 3557-3571, doi:10.5194/acp-12-3557-2012, 2012.

Bateman, A. P., Laskin, J., Laskin, A., and Nizkorodov, S. A.: Applications of high-resolution electrospray ionization mass spectrometry to measurements of average oxygen to carbon ratios in secondary organic aerosols, Environ. Sci. Technol., 46, 83158324, 2012.

Birch, M. E. and Cary, R. A.: Elemental carbon-based method for monitoring occupational exposures to particulate diesel exhaust, Aerosol Sci. Technol., 25, 221-241, 1996.

Blakney, G. T., Hendrickson, C. L., and Marshall, A. G.: Predator data station, a fast data acquisition system for advanced FTICR MS experiments, Int. J. Mass Spectrom., 306, 246-252, doi:10.1016/J.IJMS.2011.03.009, 2011. 
Carlton, A. G., Turpin, B. J., Altieri, K. E., Seitzinger, S. P., Mathur, R., Roselle, S. J., and Weber, R. J.: CMAQ model performance enhanced when in-cloud secondary organic aerosol is included: comparisons of organic carbon predictions with measurements, Environ. Sci. Technol., 42, 8798-8802, 2008.

Cavalli, F., Facchini, M. C., Decesari, S., Mircea, M., Emblico, L., Fuzzi, S., Ceburnis, D., Yoon, Y. J., O’Dowd, C.D., Putaud, J.-P., and Dell'Acqua, A.: Advances in characterization of size-resolved organic matter in marine aerosol over the North Atlantic, J. Geophys. Res., 109, D24215, doi:10.1029/2004JD005137, 2004.

China, S., Mazzoleni, C., Gorkowski, K., Aiken, A. C., and Dubey, M. K.: Morphology and mixing state of individual freshly emitted wildfire carbonaceous particles, Nat. Commun., 4, 2122, doi:10.1038/ncomms3122, 2013.

China, S., Scarnato, B., Owen, R. C., Zhang, B., Ampadu, M. T., Kumar, S., Dzepina, K., Dziobak, M. P., Fialho, P., Perlinger, J. A., Hueber, J., Helmig, D., Mazzoleni, L. R., and Mazzoleni, C.: Morphology and mixing state of aged soot particles at a remote marine free troposphere site: Implications for optical properties, Geophys. Res. Lett., 42, 1243-1250, doi:10.1002/2014GL062404, 2015.

Claeys, M., Wang, W., Vermeylen, R., Kourtchev, I., Chi, X., Farhata, Y., Surratt, J. D., Gómez-González, Y., Sciare, J., and Maenhaut, W.: Chemical characterisation of marine aerosol at Amsterdam Island during the austral summer of 2006-2007, J. Aerosol Sci., 41, 13-22, 2010.

Dinar, E., Mentel, T. F., and Rudich, Y.: The density of humic acids and humic like substances (HULIS) from fresh and aged wood burning and pollution aerosol particles, Atmos. Chem. Phys., 6, 5213-5224, doi:10.5194/acp-6-5213-2006, 2006.

Dunlea, E. J., DeCarlo, P. F., Aiken, A. C., Kimmel, J. R., Peltier, R. E., Weber, R. J., Tomlinson, J., Collins, D. R., Shinozuka, Y., McNaughton, C. S., Howell, S. G., Clarke, A. D., Emmons, L. K., Apel, E. C., Pfister, G. G., van Donkelaar, A., Martin, R. V., Millet, D. B., Heald, C. L., and Jimenez, J. L.: Evolution of Asian aerosols during transpacific transport in INTEX-B, Atmos. Chem. Phys., 9, 7257-7287, doi:10.5194/acp-9-7257-2009, 2009.

Ervens, B. and Volkamer, R.: Glyoxal processing by aerosol multiphase chemistry: towards a kinetic modeling framework of secondary organic aerosol formation in aqueous particles, Atmos. Chem. Phys., 10, 8219-8244, doi:10.5194/acp-10-8219-2010, 2010.

Ervens, B., Turpin, B. J., and Weber, R. J.: Secondary organic aerosol formation in cloud droplets and aqueous particles (aqSOA): a review of laboratory, field and model studies, Atmos. Chem. Phys., 11, 11069-11102, doi:10.5194/acp-1111069-2011, 2011.

Fialho, P., Hansen, A. D. A., and Honrath, R. E.: Absorption coefficients by aerosols in remote areas: a new approach to decouple dust and black carbon absorption coefficients using sevenwavelength Aethalometer data, J. Aerosol Sci., 36, 267-282, 2005.

Fialho, P., Freitas, M. C., Barata, F., Vieira, B., Hansen, A. D. A., and Honrath, R. E.: The Aethalometer calibration and determination of iron concentration in dust aerosols, J. Aerosol Sci., 37, 1497-1506, 2006.
Fischer, E. V., Jacob, D. J., Yantosca, R. M., Sulprizio, M. P., Millet, D. B., Mao, J., Paulot, F., Singh, H. B., Roiger, A., Ries, L., Talbot, R. W., Dzepina, K., and Pandey Deolal, S.: Atmospheric peroxyacetyl nitrate (PAN): a global budget and source attribution, Atmos. Chem. Phys., 14, 2679-2698, doi:10.5194/acp-142679-2014, 2014

Fu, P., Kawamura, K., and Miura, K.: Molecular characterization of marine organic aerosols collected during a round-the-world cruise, J. Geophys. Res., 116, D13302, doi:10.1029/2011JD015604, 2011.

Graber, E. R. and Rudich, Y.: Atmospheric HULIS: How humic-like are they? A comprehensive and critical review, Atmos. Chem. Phys., 6, 729-753, doi:10.5194/acp-6-729-2006, 2006.

Hallar, A. G., Lowenthal, D. H., Clegg, S. L., Samburova, V., Taylor, N., Mazzoleni, L. R., Zielinska, B. K., Kristensen, T. B., Chirokova, G., McCubbin, I. B., Dodson, C., and Collins, D.: Chemical and hygroscopic properties of aerosol organics at Storm Peak Laboratory, J. Geophys. Res., 118, 4767-4779, doi:10.1002/jgrd.50373, 2013.

Hallquist, M., Wenger, J. C., Baltensperger, U., Rudich, Y., Simpson, D., Claeys, M., Dommen, J., Donahue, N. M., George, C., Goldstein, A. H., Hamilton, J. F., Herrmann, H., Hoffmann, T., Iinuma, Y., Jang, M., Jenkin, M. E., Jimenez, J. L., Kiendler-Scharr, A., Maenhaut, W., McFiggans, G., Mentel, Th. F., Monod, A., Prévôt, A. S. H., Seinfeld, J. H., Surratt, J. D., Szmigielski, R., and Wildt, J.: The formation, properties and impact of secondary organic aerosol: current and emerging issues, Atmos. Chem. Phys., 9, 5155-5236, doi:10.5194/acp-9-51552009, 2009.

Helmig, D., Tanner, D. M., Honrath, R. E., Owen, R. C., and Parrish, D. D.: Nonmethane hydrocarbons at Pico Mountain, Azores: 1. Oxidation chemistry in the North Atlantic region, J. Geophys. Res., 113, D20S91, doi:10.1029/2007JD008930, 2008.

Helmig, D., Munoz, M., Hueber, J., Mazzoleni, C., Mazzoleni, L., Owen, R. C., Val Martin, M., Fialho, P., Plass-Duelmer, C., Palmer, P., Lewis, A., and Pfister, G.: Climatology and atmospheric chemistry of non-methane hydrocarbon emissions over the North Atlantic, Elementa, submitted, 2015.

Hockaday, W. C., Grannas, A. M., Kim, S., and Hatcher, P. G.: Direct molecular evidence for the degradation and mobility of black carbon in soils from ultrahigh-resolution mass spectral analysis of dissolved organic matter from a fire-impacted forest soil, Org. Geochem., 37, 501-510, 2006.

Holmes, B. J. and Petrucci, G. A.: Water-soluble oligomer formation from acid-catalyzed reactions of levoglucosan in proxies of atmospheric aqueous aerosols, Environ. Sci. Technol., 40, 49834989, 2006.

Honrath, R. E., Owen, R. C., Val Martin, M., Reid, J. S., Lapina, K., Fialho, P., Dziobak, M. P., Kleissl, J., and Westphal, D. L.: Regional and hemispheric impacts of anthropogenic and biomass burning emissions on summertime $\mathrm{CO}$ and $\mathrm{O}_{3}$ in the North Atlantic lower free troposphere, J. Geophys. Res, 109, D24310, doi:10.1029/2004JD005147, 2004.

Honrath, R. E., Helmig, D., Owen, R. C., Parrish, D. D., and Tanner, D. M.: Nonmethane hydrocarbons at Pico Mountain, Azores: 2. Event-specific analyses of the impacts of mixing and photochemistry on hydrocarbon ratios, J. Geophys. Res., 113, D20S92, doi:10.1029/2008JD009832, 2008. 
Hughey, C. A., Hendrickson, C. L., Rodgers, R. P., Marshall, A. G., and Qian, K.: Kendrick mass defect spectrum: a compact visual analysis for ultrahigh-resolution broadband mass spectra, Anal. Chem., 73, 4676-4681, 2001.

IPCC: Intergovernmental Panel on Climate Change, Climate Change 2013: The Scientific Basis. Cambridge University Press, Cambridge, England, 2013.

Kanakidou, M., Seinfeld, J. H., Pandis, S. N., Barnes, I., Dentener, F. J., Facchini, M. C., Van Dingenen, R., Ervens, B., Nenes, A., Nielsen, C. J., Swietlicki, E., Putaud, J. P., Balkanski, Y., Fuzzi, S., Horth, J., Moortgat, G. K., Winterhalter, R., Myhre, C. E. L., Tsigaridis, K., Vignati, E., Stephanou, E. G., and Wilson, J.: Organic aerosol and global climate modelling: a review, Atmos. Chem. Phys., 5, 1053-1123, doi:10.5194/acp-5-1053-2005, 2005.

Kim, S., Rodgers, R. P., and Marshall, A. G.: Truly "exact" mass: Elemental composition can be determined uniquely from molecular mass measurement at similar to $0.1 \mathrm{mDa}$ accuracy for molecules up to similar to $500 \mathrm{Da}$, Int. J. Mass Spectrom., 251, 260-265, 2006.

Kleissl, J., Honrath, R. E., Dziobak, M. P., Tanner, D., Val Martin, M., Owen, R. C., and Helmig, D.: Occurrence of upslope flows at the Pico mountain top observatory: a case study of orographic flows on a small, volcanic island, J. Geophys. Res., 112, D10S35, doi:10.1029/2006JD007565, 2007.

Kourtchev, I., Fuller, S., Aalto, J., Ruuskanen, T. M., McLeod, M. W., Maenhaut, W., Jones, R., Kulmala, M., and Kalberer, M.: Molecular composition of boreal forest aerosol from Hyytiäaläa, Finland, using ultrahigh resolution mass spectrometry, Environ. Sci. Technol., 47, 4069-4079, 2013.

Kroll, J. H., Smith, J. D., Che, D. L., Kessler, S. H., Worsnop, D. R., and Wilson, K. R.: Measurement of fragmentation and functionalization pathways in the heterogeneous oxidation of oxidized organic aerosol, Phys. Chem. Chem. Phys., 11, 8005-8014, 2009.

Kundu, S., Fisseha, R., Putman, A. L., Rahn, T. A., and Mazzoleni, L. R.: High molecular weight SOA formation during limonene ozonolysis: insights from ultrahigh-resolution FT-ICR mass spectrometry characterization, Atmos. Chem. Phys., 12, 5523-5536, doi:10.5194/acp-12-5523-2012, 2012.

Lapina, K., Honrath, R. E., Owen, R. C., Val Martin, M., and Pfister, G.: Evidence of significant large-scale impacts of boreal fires on ozone levels in the midlatitude Northern Hemisphere free troposphere, Geophys. Res. Lett., 33, L10815, doi:10.1029/2006GL025878, 2006.

LeClair, J. P., Collett, J. L., and Mazzoleni, L. R.: Fragmentation analysis of water-soluble atmospheric organic matter using ultrahigh-resolution FT-ICR mass spectrometry, Environ. Sci. Technol., 46, 4312-4322, 2012.

Levy, R. C., Remer, L. A., Mattoo, S., Vermote, E., and Kaufman, Y. J.: Second-generation algorithm for retrieving aerosol properties over land from MODIS spectral reflectance, J. Geophys. Res., 112, D13211, doi:10.1029/2006JD007811, 2007.

Lin, P., Rincon, A. G., Kalberer, M., and Yu, J. Z.: Elemental composition of HULIS in the Pearl River Delta region, China: results inferred from positive and negative electrospray high resolution mass spectrometric data, Environ. Sci. Technol., 46, 7454-7462, 2012a.

Lin, P., Yu, J. Z., Engling, G., and Kalberer, M.: Organosulfates in humic-like substance fraction isolated from aerosols at seven lo- cations in East Asia: a study by ultra-high-resolution mass spectrometry, Environ. Sci. Technol., 46, 13118-13127, 2012b.

Mazzoleni, L. R., Ehrmann, B. M., Shen, X., Marshall, A. G., and Collett Jr., J. L.: Water-soluble atmospheric organic matter in fog: exact masses and chemical formula identification by ultrahighresolution Fourier transform ion cyclotron resonance mass spectrometry, Environ. Sci. Technol., 44, 3690-3697, 2010.

Mazzoleni, L. R., Saranjampour, P., Dalbec, M. M., Samburova, V., Hallar, A. G., Zielinska, B., Lowenthal, D., and Kohl, S.: Identification of water-soluble organic carbon in nonurban aerosols using ultrahigh-resolution FT-ICR mass spectrometry: organic anions, Environ. Chem., 9, 285-297, 2012.

McClure-Begley, A., Petropavlovskikh, I., and Oltmans, S.: NOAA Global Monitoring Surface Ozone Network, 1973-2014, National Oceanic and Atmospheric Administration, Earth Systems Research Laboratory Global Monitoring Division. Boulder, CO, doi:10.7289/V57P8WBF, 2014.

Mead, R. N., Mullaugh, K. M., Brooks Avery, G., Kieber, R. J., Willey, J. D., and Podgorski, D. C.: Insights into dissolved organic matter complexity in rainwater from continental and coastal storms by ultrahigh resolution Fourier transform ion cyclotron resonance mass spectrometry, Atmos. Chem. Phys., 13, 48294838, doi:10.5194/acp-13-4829-2013, 2013.

NASA and University of Maryland: MODIS Hotspot/Active Fire Detections, Data set, MODIS Rapid Response Project, NASA/GSFC (producer), University of Maryland, Fire Information for Resource Management System (distributors), available at: http://maps.geog.umd.edu, data downloaded from https://firms.modaps.eosdis.nasa.gov/download/tmp/ firms87721385430301_MCD14ML.zip, (last access: 26 November 2013), 2002.

Ng, N. L., Canagaratna, M. R., Jimenez, J. L., Chhabra, P. S., Seinfeld, J. H., and Worsnop, D. R.: Changes in organic aerosol composition with aging inferred from aerosol mass spectra, Atmos. Chem. Phys., 11, 6465-6474, doi:10.5194/acp-11-64652011, 2011.

Nguyen, T. B., Laskin, A., Laskin, J., and Nizkorodov, S.A.: Brown carbon formation from ketoaldehydes of biogenic monoterpenes, Faraday Discuss., 165, 473-494, doi:10.1039/C3FD00036B, 2013.

Nizkorodov, S. A., Laskin, J., and Laskin, A.: Molecular chemistry of organic aerosols through the application of high resolution mass spectrometry, Phys. Chem. Chem. Phys., 13, 3612-3629, 2011.

NOAA National Climatic Data Center, State of the Climate: Wildfires for September 2012, published online October 2012, retrieved on 27 January 2014 from http://www.ncdc.noaa.gov/sotc/ fire/2012/9, 2012.

O’Brien, R. E., Laskin, A., Laskin, J., Liu, S., Weber, R., Russell, L. M., and Goldstein, A. H.: Molecular characterization of organic aerosol using nanospray desorption/electrospray ionization mass spectrometry: CalNex 2010 field study, Atmos. Environ., 68, 265-272, 2013.

O’Dowd, C. D., Smith, M. H., Consterdine, I. E., and Lowe, J. A.: Marine aerosol, sea-salt, and the marine sulphur cycle: a short review, Atmos. Environ., 31, 73-80, 1997.

Ovadnevaite, J., Ceburnis, D., Leinert, S., Dall'Osto, M., Canagaratna, M., O'Doherty, S., Berresheim, H., and O'Dowd, C.: Submicron NE Atlantic marine aerosol chemical com- 
position and abundance: Seasonal trends and air mass categorization, J. Geophys. Res. Atmos., 119, 11850-11863, doi:10.1002/2013JD021330, 2014.

Owen, R. C., Cooper, O. R., Stohl, A., and Honrath, R. E.: An analysis of the mechanisms of North American pollutant transport to the central North Atlantic lower free troposphere, J. Geophys. Res., 111, D23S58, doi:10.1029/2006JD007062, 2006.

Owen, R. C. and Honrath, R. E.: Technical note: a new method for the Lagrangian tracking of pollution plumes from source to receptor using gridded model output, Atmos. Chem. Phys., 9, 2577-2595, 2009,

http://www.atmos-chem-phys.net/9/2577/2009/.

Pan, X., Underwood, J. S., Xing, J.-H., Mang, S. A., and Nizkorodov, S. A.: Photodegradation of secondary organic aerosol generated from limonene oxidation by ozone studied with chemical ionization mass spectrometry, Atmos. Chem. Phys., 9, 38513865, doi:10.5194/acp-9-3851-2009, 2009.

Pfister, G. G., Emmons, L. K., Hess, P. G., Honrath, R. E., Lamarque, J. F., Val Martin, M., Owen, R. C., Avery, M. A., Browell, E. V., Holloway, J. S., Nedelec, P., Purvis, R., Ryerson, T. B., Sachse, G. W., and Schlager, H.: Ozone production from the 2004 North American boreal fires, J. Geophys. Res., 111, D24S07, doi:10.1029/2006JD007695, 2006.

Pitchford, M., Malm, W., Schichtel, B., Kumar, N., Lowenthal, D., and Hand, J.: Revised algorithm for estimating light extinction from IMPROVE particle speciation data, J. Air Waste Manage. Assoc., 57, 1326-1336, 2007.

Pósfai, M., Simonics, R., Li, J., Hobbs, P. V., and Buseck, P. R.: Individual aerosol particles from biomass burning in southern Africa: 1. Compositions and size distributions of carbonaceous particles, J. Geophys. Res., 108, 8483, doi:10.1029/2002JD002291, 2003.

Pósfai, M., Gelencsér, A., Simonics, R., Arató, K., Li, J., Hobbs, P. V., and Buseck, P. R.: Atmospheric tar balls: particles from biomass and biofuel burning, J. Geophys. Res., 109, D06213, doi:10.1029/2003JD004169, 2004.

Ramanathan, V., Crutzen, P. J., Lelieveld, J., Mitra, A. P., Althausen, D., Anderson, J., Andreae, M. O., Cantrell, W., Cass, G. R., Chung, C. E., Clarke, A. D., Coakley, J. A., Collins, W. D., Conant, W. C., Dulac, F., Heintzenberg, J., Heymsfield, A. J., Holben, B., Howell, S., Hudson, J., Jayaraman, A., Kiehl, J. T., Krishnamurti, T. N., Lubin, D., McFarquhar, G., Novakov, T., Ogren, J. A., Podgorny, I. A., Prather, K., Priestly, K., Prospero, J. M., Quinn, P. K., Rajeev, K., Rasch, P., Rupert, S., Sadourny, R., Satheesh, S. K., Shaw, G. E., Sheridan, P., and Valero, F. P. J.: Indian Ocean Experiment: An integrated analysis of the climate forcing and effects of the great Indo-Asian haze, J. Geophys. Res., 106, 28371-28398, 2001.

Ramanathan, V., Li, F., Ramana, M. V., Praveen, P. S., Kim, D., Corrigan, C. E., Nguyen, H., Stone, E. A., Schauer, J. J., Carmichael, G. R., Adhikary, B., and Yoon, S. C.: Atmospheric brown clouds: Hemispherical and regional variations in long-range transport, absorption, and radiative forcing, J. Geophys. Res., 112, D22S21, doi:10.1029/2006JD008124, 2007.

Reemtsma, T.: Determination of molecular formulas of natural organic matter molecules by (ultra-) high-resolution mass spectrometry: Status and needs, J. Chromatogr. A, 1216, 3687-3701, 2009.
Remillard, J., Kollias, P., Luke, E., and Wood, R.: Marine Boundary Layer Cloud Observations in the Azores, J. Climate, 25, 73817398, 2012.

Rinaldi, M., Decesari, S., Finessi, E., Giulianelli, L., Carbone, C., Fuzzi, S., O’Dowd, C. D., Ceburnis, D., and Facchini, M. C.: Primary and secondary organic marine aerosol and oceanic biological activity: recent results and new perspectives for future studies, Adv. Meteorol., 2010, 310682, doi:10.1155/2010/310682, 2010.

Sareen, N., Moussa, S. G., and McNeill, V. F.: Photochemical aging of light-absorbing secondary organic aerosol material, J. Phys. Chem. A, 117, 2987-2996, doi:10.1021/jp309413j, 2013.

Saxena, P. and Hildemann, L. M.: Water-soluble organics in atmospheric particles: A critical review of the literature and application of thermodynamics to identify candidate compounds, J. Atmos. Chem., 24, 57-109, 1996.

Schmale, J., Schneider, J., Nemitz, E., Tang, Y. S., Dragosits, U., Blackall, T. D., Trathan, P. N., Phillips, G. J., Sutton, M., and Braban, C. F.: Sub-Antarctic marine aerosol: dominant contributions from biogenic sources, Atmos. Chem. Phys., 13, 86698694, doi:10.5194/acp-13-8669-2013, 2013.

Schmitt-Kopplin, P., Gelencser, A., Dabek-Zlotorzynska, E., Kiss, G., Hertkorn, N., Harir, M., Hong, Y., and Gebefugi, I.: Analysis of the unresolved organic fraction in atmospheric aerosols with ultrahigh-resolution mass spectrometry and nuclear magnetic resonance spectroscopy: organosulfates as photochemical smog constituents, Anal. Chem., 82, 8017-8026, 2010.

Schmitt-Kopplin, P., Liger-Belair, G., Koch, B. P., Flerus, R., Kattner, G., Harir, M., Kanawati, B., Lucio, M., Tziotis, D., Hertkorn, N., and Gebefügi, I.: Dissolved organic matter in sea spray: a transfer study from marine surface water to aerosols, Biogeosciences, 9, 1571-1582, doi:10.5194/bg-9-1571-2012, 2012.

Shapiro, E. L., Szprengiel, J., Sareen, N., Jen, C. N., Giordano, M. R., and McNeill, V. F.: Light-absorbing secondary organic material formed by glyoxal in aqueous aerosol mimics, Atmos. Chem. Phys., 9, 2289-2300, doi:10.5194/acp-9-2289-2009, 2009.

Simoneit, B. R. T.: Biomass burning: a review of organic tracers for smoke from incomplete combustion, Appl. Geochem., 17, 129$162,2002$.

Simoneit, B. R. T. and Elias, V. O.: Detecting Organic Tracers from Biomass Burning in the Atmosphere, Marine Pollut. Bull., 42, 805-810, 2001.

Stenson, A. C., Marshall, A. G., and Cooper, W. T.: Exact masses and chemical formulas of individual Suwannee River fulvic acids from ultrahigh resolution electrospray ionization Fourier transform ion cyclotron resonance mass spectra, Anal. Chem., 75, 1275-1284, 2003.

Stohl, A., Hittenberger, M., and Wotawa, G.: Validation of the Lagrangian particle dispersion model FLEXPART against largescale tracer experiment data, Atmos. Environ., 32, 4245-4264, 1998.

Sun, Y. L., Zhang, Q., Anastasio, C., and Sun, J.: Insights into secondary organic aerosol formed via aqueous-phase reactions of phenolic compounds based on high resolution mass spectrometry, Atmos. Chem. Phys., 10, 4809-4822, doi:10.5194/acp-104809-2010, 2010.

Sun, Y., Zhang, Q., Zheng, M., Ding, X., Edgerton, E. S., and Wang, $\mathrm{X}$.: Characterization and source apportionment of water-soluble organic matter in atmospheric fine particles $\left(\mathrm{PM}_{2.5}\right)$ with high- 
resolution aerosol mass spectrometry and GC-MS, Environ. Sci. Technol., 45, 4854-4861, 2011.

Tanner, D., Helmig, D., Hueber, J., and Goldan, P.: A gas chromatography system for the automated, unattended, and cryogenfree monitoring of $\mathrm{C} 2$ to $\mathrm{C} 6$ non-methane hydrocarbons in the remote troposphere, J. Chromatogr. A, 1111, 76-88, 2006.

Tao, S., Lu, X., Levac, N., Bateman, A. P., Nguyen, T. B., Bones, D. L., Nizkorodov, S. A., Laskin, J., Laskin, A., and Yang, X.: Molecular characterization of organosulfates in organic aerosols from Shanghai and Los Angeles urban areas by nanospraydesorption electrospray ionization high-resolution mass spectrometry, Environ. Sci. Technol., 48, 10993-11001, 2014.

Tivanski, A. V., Hopkins, R. J., Tyliszczak, T., and Gilles, M. K.: Oxygenated interface on biomass burn tar balls determined by single particle scanning transmission X-ray microscopy, J. Phys. Chem. A, 111, 5448-5458, 2007.

Val Martin, M., Honrath, R. E., Owen, R. C., Pfister, G., Fialho, P., and Barata, F.: Significant enhancements of nitrogen oxides, black carbon, and ozone in the North Atlantic lower free troposphere resulting from North American boreal wildfires, J. Geophys. Res., 111, D23S60, doi:10.1029/2006JD007530, 2006.

Val Martin, M., Honrath, R. E., Owen, R. C., and Lapina, K.: Largescale impacts of anthropogenic pollution and boreal wildfires on the nitrogen oxides over the central North Atlantic region, J. Geophys. Res., 113, D17308, doi:10.1029/2007JD009689, 2008a.

Val Martin, M., Honrath, R. E., Owen, R. C., and Li, Q. B.: Seasonal variation of nitrogen oxides in the central North Atlantic lower free troposphere, J. Geophys. Res., 113, D17307, doi:10.1029/2007JD009688, 2008b.

Wozniak, A. S., Bauer, J. E., Sleighter, R. L., Dickhut, R. M., and Hatcher, P. G.: Technical Note: Molecular characterization of aerosol-derived water soluble organic carbon using ultrahigh resolution electrospray ionization Fourier transform ion cyclotron resonance mass spectrometry, Atmos. Chem. Phys., 8, 50995111, doi:10.5194/acp-8-5099-2008, 2008.
Wozniak, A. S., Willoughby, A. S., Gurganus, S. C., and Hatcher, P. G.: Distinguishing molecular characteristics of aerosol water soluble organic matter from the 2011 trans-North Atlantic US GEOTRACES cruise, Atmos. Chem. Phys., 14, 8419-8434, doi:10.5194/acp-14-8419-2014, 2014.

Yoch, D. C.: Dimethylsulfoniopropionate: its sources, role in the marine food web, and biological degradation to dimethylsulfide, Appl. Environ. Microbiol., 68, 5804-5815, 2002.

Zhang, B., Owen, R. C., Perlinger, J. A., Kumar, A., Wu, S., Val Martin, M., Kramer, L., Helmig, D., and Honrath, R. E.: A semiLagrangian view of ozone production tendency in North American outflow in the summers of 2009 and 2010, Atmos. Chem. Phys., 14, 2267-2287, doi:10.5194/acp-14-2267-2014, 2014.

Zhang, Q., Jimenez, J. L., Canagaratna, M. R., Allan, J. D., Coe, H., Ulbrich, I., Alfarra, M. R., Takami, A., Middlebrook, A. M., Sun, Y. L., Dzepina, K., Dunlea, E., Docherty, K., DeCarlo, P. F., Salcedo, D., Onasch, T., Jayne, J. T., Miyoshi, T., Shimono, A., Hatakeyama, S., Takegawa, N., Kondo, Y., Schneider, J., Drewnick, F., Borrmann, S., Weimer, S., Demerjian, K., Williams, P., Bower, K., Bahreini, R., Cottrell, L., Griffin, R. J., Rautiainen, J., Sun, J. Y., Zhang, Y. M., and Worsnop, D. R.: Ubiquity and dominance of oxygenated species in organic aerosols in anthropogenically-influenced Northern Hemisphere midlatitudes, Geophys. Res. Lett., 34, L13801, doi:10.1029/2007GL029979, 2007.

Zhao, Y., Hallar, A. G., and Mazzoleni, L. R.: Atmospheric organic matter in clouds: exact masses and molecular formula identification using ultrahigh-resolution FT-ICR mass spectrometry, Atmos. Chem. Phys., 13, 12343-12362, doi:10.5194/acp13-12343-2013, 2013. 